University at Albany, State University of New York

Scholars Archive

\title{
Global Climate Change in U.S. High School Curricula: Portrayals of the Causes, Consequences, and Potential Responses
}

\author{
Casey R. Meehan \\ Western Technical College, meehanc@westerntc.edu \\ Brett L.M. Levy \\ University at Albany, State University of New York, bllevy@albany.edu \\ Lauren Collet-Gildard \\ University at Albany, State University of New York, Icollet@albany.edu
}

Follow this and additional works at: https://scholarsarchive.library.albany.edu/etap_fac_scholar

Part of the Curriculum and Instruction Commons

\author{
Recommended Citation \\ Meehan, Casey R.; Levy, Brett L.M.; and Collet-Gildard, Lauren, "Global Climate Change in U.S. High School \\ Curricula: Portrayals of the Causes, Consequences, and Potential Responses" (2018). Educational Theory \\ and Practice Faculty Scholarship. 30. \\ https://scholarsarchive.library.albany.edu/etap_fac_scholar/30
}

This Article is brought to you for free and open access by the Educational Theory and Practice at Scholars Archive. It has been accepted for inclusion in Educational Theory and Practice Faculty Scholarship by an authorized administrator of Scholars Archive. For more information, please contact scholarsarchive@albany.edu. 


\title{
Global Climate Change in U.S. High School Curricula: Portrayals of the Causes, Consequences, and Potential Responses
}

\author{
Casey R. Meehan \\ Western Technical College \\ meehanc@westerntc.edu \\ Brett L. M. Levy \\ University at Albany, State University of New York \\ bllevy@albany.edu \\ Lauren Collet-Gildard \\ University at Albany, State University of New York \\ lcollet@albany.edu
}

Citation Information for Published Version:

Meehan, C. R. \& Levy, B. L. M., \& Collet-Gildard, L. (2018). Global climate change in U.S. high school curricula: Portrayals of the causes, consequences, and potential responses. Science Education 102(3), 1-29. DOI: 10.1002/sce.21338

\section{Acknowledgements:}

We would like to extend our thanks to the scholars who provided support, guidance, and feedback on earlier drafts of this work, including John Rudolph, Diana Hess, Nancy Kendall, Noah Weeth Feinstein, and Simone Schweber. 


\begin{abstract}
Broad misconceptions about global climate change (GCC) could hinder efforts to address this large-scale problem, and curricular materials can play a substantial role in what students learn about GCC. This study examines how U.S. high school textbooks and supplemental curricular materials published between 2007 and 2012 portray the causes, consequences, and potential responses to GCC. Our data included text segments related to these topics in five science textbooks, four social studies textbooks, and eight sets of GCC supplemental materials. To analyze these text segments, we conducted several rounds of coding, first categorizing curricula by their acceptance of the human causes of GCC and then coding relevant text segments on several dimensions related to the consequences of and potential responses to GCC. Findings indicate that (1) about half the curricula portray human activity as a major cause of current climate change, (2) most curricula include information about climatic changes but few details about potentially proximal, near-term impacts of GCC, and (3) most curricula offer a narrow set of strategies for responding to GCC. These findings suggest that educators should critically examine curricular materials they use to teach about GCC and that scholars should continually examine how GCC is portrayed to youth.
\end{abstract}

\title{
KEYWORDS
}

climate change, curriculum, global warming, textbooks 


\section{1 | INTRODUCTION}

For years, scientists have acknowledged the existence of global climate change (GCC) and its associated risks (Anderegg, Prall, Harold, \& Schneider, 2010), such as longer droughts and more frequent extreme weather events (U.N. Framework Convention on Climate Change, 2004). Education standards have adapted to encourage educators to support students' understanding of these issues. For example, the Benchmarks for Science Literacy (American Association for the Advancement of Science [AAAS], 1993)—issued in the early 1990s, emphasize human impacts on climate and ecosystems. ${ }^{1}$ The more recent Next Generation Science Standards (2013) state that by the end of 12th grade, students should understand "how an increase in greenhouse gases causes a rise in global temperatures" (p. 97) and that climatic changes "can disrupt an ecosystem and threaten the survival of some species" (p. 87). Given that leaders in science and science education recognize the importance of GCC and its potential impact, it is important to explore how curricular materials portray these and related issues.

Curricular materials can have a substantial impact on the content that students explore in school (e.g., National Center for Educational Statistics, 2014; Schmidt, Houang, \& Cogan, 2002), but little research has examined how such materials have portrayed GCC. This paper aims to address this gap by presenting analyses of how nine textbooks and eight sets of supplemental curricular materials published between 2007 and 2012 portray the causes, consequences, and potential responses to GCC. Although these materials were published some time ago, certain districts maintain the same curricula for many years (UNESCO, 2017; Zinth, 2005)—so some of

\footnotetext{
${ }^{1}$ The Benchmarks for Science Literacy (AAAS, 1993) state that students in grades 9-12 should learn that "The burning of fossil fuels in the last century has increased the amount of greenhouse gases in the atmosphere, which has contributed to Earth's warming" (4B/H6). The National Science Education Standards (National Research Council, 1996) does not refer directly to the anthropogenic causes of GCC but rather emphasizes that "humans modify ecosystems" in ways that are "threatening current global stability" (Standard C, pp. 181-186).
} 
these may still be in use. Furthermore, it is important to understand how GCC has been portrayed at different points in history, and this study provides a framework for doing so.

Over the past two decades, leaders from around the world have gathered annually to develop plans to address GCC, so this has clearly become an issue of global importance. The Intergovernmental Panel on Climate Change (IPCC), the world's foremost international organization charged with assessing climate change, reported in 2001, 2007, and 2014 that numerous environmental changes associated with GCC, such as rising sea levels and shifting precipitation patterns, are already disrupting natural ecosystems and human societies (IPCC, 2001, 2007, 2014). ${ }^{2}$ More recently, the U.S. Department of Defense (e.g., 2014, 2015) has issued reports warning of the security challenges that could result from the increased poverty, social tensions, and resource shifts that may arise from GCC's effects. Given these potential impacts, it is vital for populations to understand the complexities of this issue, especially in democratic societies where decision-making often reflects the public will. As Dewey argued, public understanding of scientific issues and methods can facilitate wiser democratic engagement (as cited in Rudolph, 2014).

Nonetheless, a significant portion of the U.S. public disputes the basic science of GCC. According to recent data, about one fifth of the U.S. public does not believe the planet is warming at all, and between one third and one half of Americans think human activity does not contribute to GCC (Gallup, 2017; Leiserowitz, Maibach, Roser-Renouf, Feinberg, \& Rosenthal, 2015; Pew Research Center, 2016). Studies indicate that about one third of Americans think, contrary to evidence, that scientists disagree about the nature of climate change (Leiserowitz, Maibach, Roser-Renouf, Feinberg, \& Howe, 2012; Pew Research Center 2016). Whereas most

\footnotetext{
${ }^{2}$ The IPCC was established in 1988 by the World Meteorological Organization and the UN Environment Programme to assess the science related to climate change, including its impacts, future risks, and options for mitigation and adaptation.
} 
seem to believe GCC's effects can already be felt (Gallup, 2017), only a minority are concerned that GCC will start to harm people over the next 10 years (Leiserowitz et al., 2015). Thus, the study described in this paper examines how widely used U.S. high school curricular materials portray these issues.

Younger Americans (those born after 1976) are slightly more aware of the scientific consensus about GCC's causes, but they are even more likely than older generations to discount the immediate effects of the problem (Feldman, Nisbet, Leiserowitz, \& Maibach, 2010). Whereas the belief in anthropogenic causes of climate change has recently increased in some countries, such as New Zealand (Milfont, Wilson, \& Sibley, 2017), Americans' beliefs in GCC's human causes have been fairly stable over the past decade, fluctuating between 40 and 50\% (Newport, 2010; Pew Research Center, 2015, 2016), with occasional spikes after notable relevant incidents, such as Hurricane Katrina and unusually warm winters (Gallup, 2017). Unfortunately, misperceptions about this issue can make individuals less willing to undertake actions to address the problem (Herman, 2014).

On the positive side, school-based instruction can play a central role in supporting young people's learning about GCC (Nussbaum et al., 2015; Dempsey et al., 2013). Curricular materials can substantially shape teachers' instructional decisions (Ball \& Cohen, 1996). Given the influence of curricula on classroom instruction, we believe it is vital to understand what explicit and implicit messages are conveyed through these media. Although U.S. political leaders and news outlets regularly raise doubts about the anthropogenic causes of GCC and the need to address these causes (e.g., Boykoff, 2013; Feldman, Maibach, Roser-Renouf, \& Leiserowitz, 2012; Hamilton, 2011), our stance is that youth should be well-informed about both the scientific consensus around GCC's causes and the various options for responding to the problem. Through 
understanding such issues, we believe, the next generation will be better prepared to make wise decisions about the use of natural resources and thus support ecological sustainability. Thus, the study described in this paper examines how widely used U.S. high school curricular materials portray these issues.

Although prior research has analyzed climate change content in European secondary school textbooks and American middle school textbooks, no published research has examined how high school curricula in the United States, the world's second-largest emitter of greenhouse gases (Nejat, Jomehzadeh, Taheri, Gohari, \& Majid, 2015), address this global issue. To help address this gap in the literature, we present analyses of portrayals of GCC in five science textbooks, four social studies textbooks, and eight sets of supplemental materials, including what messages these curricula convey about how societies should respond to GCC. Our findings and implications can be useful to curriculum developers, teacher educators, policymakers, and researchers who are concerned about how the next generation understands this vital international challenge.

\section{2 | BACKGROUND}

To contextualize this study and its scholarly contribution, below we provide background about climate change education and the importance of fostering nuanced understandings of GCC. Then we summarize the central role of curricular materials in such work. Overall, whereas prior studies indicate that curricula can play an important role in what young people learn about GCC, there has been little research focusing on how curricula portray the causes, consequences, and potential responses to the problem. 


\section{1 | Why understanding climate change matters}

Scholars in various fields of education, including science, social studies, and environmental education, have argued that educational experiences in the 21 st century should help to prepare young people to participate in the civic and economic life of a global society (e.g., Gaudelli \& Heilman, 2009; Hodson, 2003; Youniss et al., 2002). Whereas some researchers contend that efforts to create "global citizens" are often rooted in Western, neoliberal perspectives (e.g., Bengtsson \& Ostman, 2013; Ideland \& Malmberg, 2014; Jickling \& Wals, 2008; Mannion, Biesta, Priestley, \& Ross, 2011), they generally agree that young people should develop an understanding of large-scale environmental problems, such as climate change, and how these problems may affect their lives (Wals, Weakland, \& Corcoran, 2017). Indeed, given the scale of local and international shifts associated with GCC, leaders in academia, government, and civil society assert that it is vital for youth to understand the far-reaching and long-term nature of this issue so that they and their institutions can respond wisely and collaboratively (e.g., Bencze \& Carter, 2011; Brown, 2011; Government of Canada, 2002).

Many studies have indicated that understanding a given problem is insufficient for generating action to address that problem (Kollmuss \& Agyeman, 2002). Nonetheless, basic knowledge about a serious environmental challenge can be an important building block for motivating behavior change in that domain (DeYoung, 2000; Newstadt, 2015). Indeed, although cultural norms and environmental attitudes can affect individuals' likelihood of taking pro-

environmental action (Fishbein \& Ajzen, 2010; McMakin, 2002), the population's perception of the risks of GCC may be vital to our broader ability to address it. In a study of 2,164 adults, Roser-Renouf and colleagues (Roser-Renouf, Maibach, Leiserowitz, \& Xianoquan, 2014) found a positive relationship between the expected outcomes of GCC and climate-related activism, 
controlling for a variety of background variables. Other studies have found that when individuals expect negative environmental outcomes, they are more likely to be involved in environmental activism and supportive of pro-environment government policies (Lubell, 2002; Lubell, Zahran, \& Vedlitz, 2007). Similarly, in a study of 324 secondary students, Herman (2014) found that participants' conceptions of the validity of GCC science were the most consistent predictor of their willingness to take action to mitigate the problem.

In democratic societies, civic participation, fueled by individuals' perceptions of public issues, can substantially influence policymakers' decisions (Butler \& Nickerson, 2011; Doyle \& Kellow, 1995; Shabecoff, 2003). Indeed, if individuals consider an issue to be important, that issue can shape their voting decisions (Belanger \& Meguid, 2008) and hence policy decisions. Whereas Americans now have widely varying perceptions about the risks associated with climate change (Roser-Renouf et al., 2014), ${ }^{3}$ what they learn in school can substantially affect these conceptions (see below). Thus, it is important for scholars and educators to understand how curricula portray GCC. The study described below provides a unique analysis of how widely used curricular materials in the United States depict various facets of this issue.

\section{2 | Climate change education}

\subsubsection{Empirical research on teaching and learning about GCC}

Prior research on climate change education highlights student conceptions of climate change and the quality of instruction on the issue. First, evidence indicates that youth enter the classroom with varied conceptions about GCC but that these ideas can be strengthened through appropriate instruction. Whereas some youth have a clear understanding of the causes of GCC (Caranto \&

\footnotetext{
${ }^{3}$ According to Roser-Renouf, et al. (2014), Americans' attitudes towards climate change fit into six categories: alarmed: $13 \%$, concerned: $31 \%$, cautious: $23 \%$, disengaged: $7 \%$, doubtful: $13 \%$, dismissive: $13 \%$.
} 
Pitpitunge, 2015), many middle and high students appear confused about the difference between weather and climate (Andersson \& Wallin, 2000; Porter, Weaver, \& Raptis, 2012; Pruneau, Gravel, Courque, \& Langis, 2003). Meanwhile, many students have misconceptions about the greenhouse effect. Whereas some do not know about the greenhouse effect at all (Andersson \& Wallin, 2000), others believe that the ozone layer is a major component of it (Chang \& Pascua, 2015; Pruneau et al., 2003) or hold misconceptions about its impacts and how humans can adapt (Caranto \& Pitpitunge, 2015). Chang and Pascua's (2015) study of secondary students in Singapore found that some participants thought that radioactive waste and chlorofluorocarbons (CFCs) were major causes of GCC and that GCC can trigger tectonic plate movements, acid rain, and skin cancer. The frequency of these ideas, however, declined substantially after a 6-day curriculum on the topic. Just as students' prior conceptions can develop and shift on various topics (Donovan \& Bransford, 2005), it is possible to build on or reshape students' initial ideas about GCC through appropriate instruction.

Unfortunately, some student misperceptions persist and may be related to their limited exposure to classroom instruction about the various dimensions of climate change. One survey of 628 science teachers in Colorado found that many of these educators had inaccurate knowledge of the issue, and over $80 \%$ believed that students should learn "both sides" of the debate over what causes climate change (Wise, 2010). Even in Singapore, where the national curriculum promotes teaching the scientific consensus about climate change, some teachers treat the causes of climate change as an open question (Ho \& Seow, 2015). This reluctance to accept and educate others on the consensus around the causes of GCC may be related to educators' emotional reactions to the issue, for many secondary teachers have expressed anger and hopelessness about climate change, feelings that make them less likely to teach about it (Lombardi \& Sinatra, 2012). 
However, some science teachers may avoid the issue because of their own limited understanding of GCC. In a recent study of over 200 secondary science teachers in the United States, researchers found that many educators had misperceptions about GCC — with over one quarter of participants believing that GCC science is invalid because it is largely based on modeling (Herman, Feldman, \& Vernaza-Hernandez, 2017).

Nonetheless, some studies have identified potentially useful strategies for supporting young people's understanding of GCC and educators' preparation to teach about it. For example, Hallar, McCubbin, and Wright (2011) found that a place-based science curriculum requiring students to measure and analyze local temperature, wind speed, and particle concentrations, improved students' understanding of key concepts related to GCC, such as the composition of the atmosphere and the difference between weather and climate. Another study found that students' experiences in a 10-week unit exploring multiple dimensions of GCC (e.g., carbon cycle, Earth's energy budget) supported their understanding of various elements of GCC, especially the greenhouse effect, but also suggested that students had difficulty with "systems thinking," including the complexities of cause and effect in a dynamic climate system (Roychoudhury et al., 2017). In addition, researchers have found that certain unconventional classroom experiences, such as reading "refutation texts" that explicitly address common misconceptions (Nussbaum, Cordova, \& Rehmat, 2017) or engaging in GCC-related "productive failure" prior to direct instruction (Jacobson et al., 2017), can strengthen the accuracy of students' GCC knowledge.

Meanwhile, several studies have explored how integrating socio-scientific issues (SSIs) — ethical, moral, and social issues associated with science-into science coursework can support students' scientific learning. For example, Klosterman and Sadler (2010) studied high 
school chemistry and environmental science courses that included a 3-week unit on climate change that explored both scientific topics and related political controversies. They found substantial gains in students' GCC content knowledge during the unit. Studying SSIs related to climate change can also support young people's commitment to actively respond to the problem. McNeil and Vaughn's (2012) study of a climate change curriculum enactment in three urban U.S. high schools with students primarily from low socioeconomic backgrounds concluded that examining the broad consequences of GCC along with potential mitigation actions, such as conservation, helped participants become more willing to engage in such behaviors. And Sinatra and colleagues (2012) found that when college students read a persuasive text about the causes and consequences of anthropogenic climate change, they became more willing to take action to reduce its impact. Additional studies of integrating SSIs into students' explorations of other scientific issues suggest that such approaches can support students' content knowledge and interest in science (e.g., Parchmann et al., 2006; Sadler, Romine, Stuart, \& Merle-Johnson, 2013). Thus, there have been numerous valuable studies examining the methods and results of integrating SSIs into science classes.

In addition, research indicates that including GCC content in teacher learning programs can enhance educators' preparation to teach about GCC. For example, integrating GCC topics into science methods courses can support pre-service elementary teachers' conceptions of climate change (Lambert, Lindgren, \& Bleicher, 2012) and the nature of science (Matkins \& Bell, 2007). Research on professional development programs have found that teachers from different countries may enjoy collaborating, even from a distance (i.e., online), as they begin to teach about GCC (Ferreira et al., 2012; Johnson et al., 2008). Meanwhile, building on findings about student learning progressions on GCC-related topics, such as sea level rise (e.g., 
McGinnis, McDonald, Breslyn, \& Hestness, 2017), researchers have found that educators' understanding of such learning progressions can enhance their theories of teaching and learning about GCC, including their conceptions of instructional planning and differentiation (Hestness, McGinnis, Breslyn, McDon- ald, \& Mouza, 2017). Thus, integrating GCC into teacher learning programs could enhance both their knowledge and pedagogy.

Some scholars argue that GCC is a suitable topic not only for science courses but also for social studies courses, given the social and ecological ramifications of GCC (Bisland \& Ahmand, 2008; Feinstein \& Kirchgasler, 2015; McKeown-Ice \& Dedinger, 2000; Rye, Strong, \& Rubba, 2001). One recent study examining how three social studies educators taught about GCC found that these teachers emphasized the current and future social impact of climate change and encouraged students to become involved in addressing it (Chandler \& Marri, 2012). Kumler (2011) conducted some valuable research that compares social studies and science instruction about environmental issues. In her exploration of action outcomes for social studies students and science students who had learned about sustainable land use issues during a 2-week environmental education curriculum unit, she found that social studies students demonstrated a broader range of knowledge about actions that promote sustainable land use than did science students exposed to the same curriculum. These findings suggest that social studies classrooms may be opportune settings for students to explore ways to respond to climate change. But aside from these studies, there has been little research on how students in social studies classrooms learn about GCC (Hauser, 2009).

\subsection{2 | Professional guidelines and standards related to GCC education}

In the United States, major educational organizations have developed guidelines and standards for teaching about GCC, but documents from the National Science Teachers Association 
(NSTA) and the National Council for the Social Studies (NCSS) suggest that there may be major differences in what and how students learn about GCC in science and social studies classrooms. Although neither organization has a position statement on teaching about GCC, other documents suggest ways for teachers to approach the topic. As we note in the Introduction, the Next Generation Science Standards, endorsed by the NSTA, include numerous standards related to the causes and consequences of GCC, and there are also standards related to "developing possible solutions," which suggest that students explore technical solutions for managing and moderating the impact of GCC. The NSTA position on the nature of science states that "science, along with its methods, explanations and generalizations, must be the sole focus of instruction in science classes" (NSTA, 2016). However, more recently, the NSTA position on Teaching Science and Technology in the Context of Societal and Personal Issues explains that one central purpose of science education is to "provide an authentic learning context by examining the societal dimensions of a scientific issue" and suggests that students learn to "recognize how scientific and technologic advances may affect the environment positively or negatively" (NSTA Board of Directors, 2016). Thus, although leaders in science education emphasize the importance of learning the content and methods of the field, they have more recently supported the incorporation of SSIs into classrooms.

On the other hand, social studies courses have long been venues for exploring multiple perspectives and informed action - appropriate for certain aspects of GCC, such as potential impacts and responses, but inappropriate for the considering issues on which scientific consensus has been reached, such as the human causes of GCC. The NCSS (2007) official position on academic freedom in social studies teaching stated that "Controversial issues must be studied in the classroom without the assumption that they are settled in advance or there is only one 'right' 
answer in matters of dispute. ${ }^{44}$ Continuing this approach, the recently released standards for social studies (NCSS, 2013) suggest that teachers expose students to various sides of controversial topics and support their development of action plans on those issues. This standards document barely mentions GCC at all and in one instance refers broadly to climatic changes "caused by either natural or human induced processes" (p. 97). Given that the cause of climate change is often treated as controversial in the mass media (Boykoff, 2013), social studies educators may feel the need to treat it as such. Moreover, considering the different emphases of leading organizations in science and social studies, youth in these subject area classrooms may encounter different messages about the nature of GCC and how societies and individuals might respond to it.

\section{3 | Role of curricular materials in climate change education}

Studies indicate that curricular materials play a substantial role in classroom instruction. As Ball and Cohen (1996) argue, unlike standards and objectives, curricula comprise the concrete information that teachers and students process during learning experiences and are part of the routine of classroom life. Teachers' instruction in the United States and other countries often reflects textbook sequences and topic depth (Schmidt et al., 2002). In history classrooms in the United States, for example, about $64 \%$ of students read from the textbook at least weekly (NCES, 2014), and researchers estimate that between 70 and $98 \%$ of all teachers in the United States use them during instruction weekly (Chingos \& Whitehurst, 2012). Although how teachers employ curricular materials in the classroom varies (Freeman \& Porter, 1989), research suggests that using higher quality textbooks is related to higher quality instruction (Sun, Kulm, \&

\footnotetext{
4 "Settled" issues or controversies refer to those that are not open to debate. A "settled" or "closed" issue or controversy is one on which society has generally reached consensus. However, what is considered "settled" may vary by society, domain, or local context (Hess, 2009).
} 
Capraro, 2009). Indeed, evidence suggests that curricular materials designed for students can substantially shape teachers' ideas about how to teach their content (Grossman \& Thompson, 2008). In democratic societies in which policies often reflect popular perceptions, it is important to examine how curricula portray important public issues, such as GCC. Indeed, as LadsonBillings (2016) recently argued, curriculum can be a powerful vehicle for discourse and democratic engagement.

Several researchers have found that materials used to teach about GCC do not thoroughly address the issue. For example, a study of seven commonly used earth science and environmental science textbooks found that about half of 18 major climate change concepts were absent from a majority of the texts (Choi, Nigoyi, Shepardson, \& Charusombat, 2010). In an analysis of four sixth-grade science textbooks used in California, Román and Busch (2016) found that these books framed GCC as uncertain in the scientific community, and in a study of over 50 earth science texts used in England and Wales, King (2010) found portrayals of numerous misconceptions about GCC. Meanwhile, in Canada, Chambers and Rowell (2005) found that the provincial government of Alberta produced a set of materials that frame climate science as unsettled. In a more extreme example, one commonly used college-level U.S. government textbook consistently questions the scientific consensus around GCC, calling it a product of "activist scientists" (Araujo, Jordan, \& Lindsay, 2008). In classrooms where instruction is shaped by curricular materials, these misleading portrayals could substantially affect students' learning about this issue.

Some science education materials do communicate clearly about the anthropogenic causes of climate change (Chambers \& Rowell, 2005; Dalelo, 2011; Morris, 2014), but they often do not comprehensively explore potential policy responses to this growing problem. For 
example, curriculum materials for one of England's capstone secondary school courses, TwentyFirst Century Science, provides substantial details about the scientific phenomena of GCC but only a few sentences about how humans can mitigate it (Morris, 2014), most of which are focused on individual rather than collective action. Likewise, a popular curriculum in Canada suggested that any action to mitigate climate change should be focused on voluntary actions and technological solutions (Chambers \& Rowell, 2005). An analysis of geography curriculum materials in Mexico, Romania, and Germany indicate that these materials provide general scientific background on GCC but little guidance on how to address climate change (BagoloSimo, 2013), and curriculum guides for geography courses in Ethiopia neglect potential collective mitigation efforts, such as energy efficiency (Dalelo, 2011). Despite these useful findings, no published research analyzes how U.S. high school curricular materials address potential responses to climate change, and the research described below begins to fill this gap.

\section{3 | RESEARCH QUESTIONS}

This study is shaped by the following central questions: Overall, how do curricular materials used in U.S. high school classrooms portray the causes, consequences, and potential responses to GCC? Specifically, what are the similarities and differences among nine textbooks and eight sets of supplemental materials in their portrayals of these aspects of GCC? Our findings have important implications for scholars, educators, policymakers, and other civic actors interested in fostering thorough conceptions of complex large-scale public issues. 


\section{4 | METHODS}

To address these questions, this study involved a qualitative analysis of nine widely used U.S. high school textbooks (five science, four social studies) and eight sets of supplemental materials developed by not-for-profit and governmental organizations for use in U.S. high school classrooms. We selected curricula intended for science and social studies courses because these subject areas, according their standards and traditions, both address issues related to GCC. Whereas high school science courses have long explored issues related to weather and climate, secondary social studies courses (especially those in civics and government) often examine how citizens and the public respond to collective challenges. Textbooks play a central role in shaping curricula in high school science and social studies classrooms in the United States (Blystone, 1989; Wade, 1993), and teachers also make use of supplemental curricula because they can be sources of up-to-date information and are easy to access via the Internet. Analyzing supplemental curricula is important because the content included in them may be more prone to promoting particular ideologies than textbooks, the content of which is often closely scrutinized (Hess \& Stoddard, 2007).

\section{1 | Data sources}

The curricular materials analyzed below were selected for this study based on three general criteria. First, they needed to be designed for U.S. high school students. Second, they had to be published subsequent to the release of the 2007 IPCC report so that all curriculum developers had an opportunity to learn about its strong findings confirming the human causes of GCC. (The 2007 report states, "There is very high confidence that the global average net effect of human 
activities since 1750 has been one of warming" [p. 37].) Finally, all data sources needed to relate to at least one discipline within social studies or science content areas. ${ }^{5}$

In addition, textbooks were selected based on their widespread use. The first author used data from textbook industry analysts (Education Market Research, 2010) to identify top-selling U.S. high school textbooks in several science and social studies content areas, including physical science, physics, chemistry, biology, earth science, civics/government, U.S. history, world history, geography, and economics. WorldCat was then used to locate and obtain the most recent editions available of the first and second most purchased books in each of these disciplines. For each textbook, the first author reviewed the table of contents to look for key words and phrases indicating content about GCC, including climate, climate change, GCC, global warming, and greenhouse effect. Next, the index was searched for the same key terms as well as other terms that may have signified discipline-specific information about GCC, including the terms Kyoto Protocol, IPCC, environment, carbon cycle, and cap and trade. The textbooks with enough GCCrelated content to analyze (at least five sentences) focused on geography, earth science, biology, and world history. To expand the analysis, two other texts—an advanced placement (AP) world geography text and an AP environmental science text, both recommended by the College Board-were also selected for analysis. After these texts were identified, the first author scanned and

\footnotetext{
${ }^{5}$ For much of this paper, we classify curricula into two broad content categories, science and social studies, but many of the supplemental materials reference two or more sets of standards (e.g. the National Science Education Standards, Environmental Education Guidelines for Excellence). Consequently, in some tables and sections below, textbooks and supplemental materials that focused exclusively on social studies standards were classified as "social studies-focused" and all others as "non-social studies-focused."
} 
CLIMATE CHANGE IN U.S. HIGH SCHOOL CURRICULA 19

TABLE 1 | Sample of textbooks

\begin{tabular}{lcc}
\hline $\begin{array}{c}\text { Content Area } \\
\text { Textbook Title }\end{array}$ & Year of & Publisher \\
& Publication & \\
\hline
\end{tabular}

\section{SCIENCE TEXTBOOKS}

\section{Biology}

Biology

Earth Science

Earth Science

Earth Science: Geology, the Environment, and the Universe

Earth Science

\section{A.P. Environmental Science}

Living in the Environment: Concepts, Connections, and Solutions (16th Ed.)

\section{SOCIAL STUDIES TEXTBOOKS}

\section{World History}

Modern World History: Patterns of Interaction

\section{World Geography}

World Geography: Building a Global Perspective

World Geography and Cultures

\section{A.P. Human Geography}

Human Geography: Landscapes of Human Activities (11th. Ed.)
2008 Pearson Prentice Hall

2009 Pearson Prentice Hall

2009 Glencoe/McGraw-Hill

2010 Holt McDougal, Houghton Mifflin

2009 Brooks/Cole, Cengage Learning
2009 McDougal Littell

2009 Pearson Prentice Hall

2012 Glencoe/McGraw-Hill

$2010 \quad$ McGraw-Hill 
printed all relevant pages of those textbooks. Given that these are top-selling textbooks, millions of students have likely encountered this content (see Table 1). ${ }^{6}$

For supplemental materials, this study included materials that met the three criteria discussed above as well as several other guidelines. First, the materials needed to contain content explicitly about GCC as a central part of the lesson(s) (as opposed to materials that implicitly taught about it, such as materials about energy education). Second, supplemental curricula needed to include at least one formal lesson plan that the curriculum writers intended to be used by a teacher in a formal classroom for at least one 45-minute class period. Third, supplemental materials had to be produced as a coherent set of materials for an organization's GCC education initiative.

Supplemental materials were located using recommendations from experts, practitioners, and organizations in the fields of social studies education, science education, and environmental education. Materials were also found via thorough searches of websites hosted by climate change curricula clearinghouses (e.g., climatechangeeducation.org) and education sections of websites hosted by fossil fuel corporations (e.g., BP, Chevron, and Exxon Mobil). This search yielded 16 sets of potential supplemental materials. The first author consulted with experts in social studies education and science education to rate each set of materials on its developmental appropriateness, coherence, feasibility for use in a classroom setting, and overall quality—and then removed from consideration any materials deemed pedagogically unsound or infeasible. Finally, from the remaining supplemental materials, purposeful sampling (Patton, 2002) was used to select materials with diversity by ideology and content focus (see Table 2). Although we

\footnotetext{
${ }^{6}$ Unfortunately, the financial cost of obtaining specific information regarding the number of students who are exposed to these textbooks was prohibitive.
} 
are uncertain how many teachers are actually using these materials, Internet searches and conversations with teachers suggest that many are used frequently in classrooms.

TABLE 2 | Sample of supplemental curricula

\begin{tabular}{|c|c|c|c|c|}
\hline Curriculum Title & Organization & $\begin{array}{l}\text { Year of } \\
\text { Publicati } \\
\text { on }\end{array}$ & $\begin{array}{l}\text { Content Areas } \\
\text { Explicitly } \\
\text { Referenced }\end{array}$ & $\begin{array}{c}\text { Approximate } \\
\text { Dissemination \& } \\
\text { Use }\end{array}$ \\
\hline $\begin{array}{l}\text { An Inconvenient Truth } \\
\text { in the Classroom }\end{array}$ & $\begin{array}{l}\text { National Wildlife } \\
\text { Federation }\end{array}$ & 2008 & $\mathrm{EE}^{a}$ & $\begin{array}{l}\text { No information } \\
\text { available }\end{array}$ \\
\hline Global Warming 101 & $\begin{array}{l}\text { Will Steger } \\
\text { Foundation }\end{array}$ & 2009 & $\begin{array}{l}\text { Social Studies, } \\
\text { Science, EE, other } \\
b\end{array}$ & 550 downloads \\
\hline $\begin{array}{l}\text { Climate Change: A } \\
\text { Wisconsin Activity } \\
\text { Guide }\end{array}$ & $\begin{array}{l}\text { Wisconsin } \\
\text { Department } \\
\text { of Natural } \\
\text { Resources }\end{array}$ & 2009 & $\begin{array}{l}\text { Social Studies, } \\
\text { Science, EE, other } \\
b\end{array}$ & $\begin{array}{l}4,427 \text { copies } \\
\text { distributed }\end{array}$ \\
\hline $\begin{array}{l}\text { Climate Change: } \\
\text { Connections \& } \\
\text { Solutions }\end{array}$ & Facing the Future & 2007 & $\begin{array}{l}\text { Social Studies, } \\
\text { Science, EE }\end{array}$ & $\begin{array}{l}\text { No information } \\
\text { available }\end{array}$ \\
\hline $\begin{array}{l}\text { Deliberating in a } \\
\text { Democracy: Global } \\
\text { Climate Change }\end{array}$ & $\begin{array}{l}\text { Constitutional } \\
\text { Rights } \\
\text { Foundation- } \\
\text { Chicago }\end{array}$ & 2009 & Social Studies ${ }^{c}$ & $\begin{array}{l}\text { No information } \\
\text { available }\end{array}$ \\
\hline $\begin{array}{l}\text { Global Environmental } \\
\text { Problems: Implications } \\
\text { for US Policy }\end{array}$ & $\begin{array}{l}\text { Choices for the } \\
\text { 21st Century } \\
\text { (Brown University) }\end{array}$ & 2009 & Social Studies & $\begin{array}{l}6,000 \text { copies } \\
\text { distributed }\end{array}$ \\
\hline $\begin{array}{l}\text { Understanding Climate } \\
\text { Change: Lesson Plans } \\
\text { for the Classroom }\end{array}$ & $\begin{array}{l}\text { The Frasier } \\
\text { Institute }\end{array}$ & 2009 & none ${ }^{d}$ & $\begin{array}{l}\text { No information } \\
\text { available }\end{array}$ \\
\hline Unstoppable Solar Cycles & Izzit.org & 2008 & none ${ }^{d}$ & $\begin{array}{l}475,000 \text { copies } \\
\text { distributed }\end{array}$ \\
\hline
\end{tabular}


The curriculum selection and initial analysis occurred in 2012 as part of the first author's dissertation, and we maintained the integrity of the sample as we fine-tuned the analyses and revised the paper. Thus, at the time of initial analyses, these materials were quite current, and though they are now more dated, some of them are likely still in use. Regardless, sharing our analyses of older curricula can now provide valuable insights into not only how curricula from 2007 to 2012 portrayed GCC but also how such materials can be carefully analyzed based on various dimensions of GCC.

\subsection{Data analysis}

We conducted several rounds of coding to analyze the text segments related to GCC. To begin, the first author sorted the GCC content of each source into three broad a priori categories: causes of GCC, effects of GCC, and means of responding to GCC. These categories echo frameworks employed by the National Research Council (n.d.) and NASA (2017). Then, to examine how the curricular materials portrayed GCC causes, the first author categorized these texts by the extent to which they conceptualize anthropogenic GCC as an open question (unsettled issue) or closed question (settled issue). Whereas an open question is one for which multiple answers are possible, a closed question is one for which educators expect learners to come away with one particular answer (Hess, 2009). These initial analyses resulted in the creation of three categories of GCC curricula: adherent, hesitant, and dissenting. Whereas adherent curricula firmly presented human activity as a major cause of GCC (i.e., as a closed question), the text of hesitant curricula employed language that was less definitive about the human contributions to climate change (e.g., as an open question). Meanwhile, dissenting curricula strongly rejected the idea that humans contributed to GCC (closed question), in some 
cases expressing doubt about whether or not the climate was changing at all. As text segments in each category were examined line by line, we conducted open coding (Corbin \& Strauss, 2008) to identify subcodes, such as the seriousness of GCC and the existence of scientific consensus. (Sample codes include driver-anthropogenic, driver-natural; consequences-where, consequenceswhen, consequences-who.)

Next, to identify differences in how these three types of curricula portrayed the consequences of GCC, we drew on findings from the 2007 IPCC Synthesis Report. The report discusses four broad effects of climate change (rising average temperatures, rising sea levels, increases in extreme weather events, and changes in precipitation patterns) and five spheres of impact due to rapidly changing climates (impacts to ecosystems, water resources, food resources, human health, and human settlements and society). We identified text segments in each curricular resource that fit into each of these conceptual categories, first quantifying the attention given to each subtopic (by number of sentences). Then, drawing on the temporal and spatial dimensions identified by Brace and Geoghegan (2011), we labeled these text segments with codes based on when (now, soon, indeterminate) and where (close, far, indeterminate) the curricular materials suggested these GCC impacts would occur.

To analyze text segments related the potential responses to GCC, we drew on response categories identified by previous research (e.g., IPCC, 2007, 2014; Launder \& Thompson, 2010): mitigation, adaption, and geo-engineering. Whereas mitigation refers to how humans can reduce the causes of climate change, such as greenhouse gas emissions, adaptation includes ways that we can adapt to the changing climate. Meanwhile, geo-engineering techniques are methods, often conceptual and untested, that could help to avert, reduce, or reverse GCC. Although some researchers consider geo-engineering techniques unlikely to address GCC and potentially 
harmful (Svoboda, Keller, Goes, \& Tuana, 2011), others view such options vital to explore, given the limits of current mitigation efforts (Macnaghten \& Szersynski, 2017; Preston, 2011). Thus, in our analysis, we explored how curricula portrayed the issue. Within these three broad coding categories - mitigation, adaptation, and geo-engineering, we developed several subcodes based on what appeared in the text segments. For example, subcodes of mitigation approaches included individual energy conservation, cap-and-trade systems, and "green" technology. Then we counted the number of sentences that each text allocated to each of these concepts. Occasionally the texts, especially dissenting curricula, were dismissive of certain response options. Because these options were not portrayed as reasonable pursuits, we did not include these segments in our sentence count.

For each code and subcode, we developed clear definitions (see the Appendix) and then coded the text segments based on these definitions. When the appropriate code for a text segment was unclear, we discussed it as a group, decided where to place it, and revised code definitions if necessary (e.g., one text segment on mitigation mentioned how governments can support renewable energy development, and instead of placing it only in the "laws and regulations" category, our group discussion prompted us to also code it as "green technology." Such discussions occurred for only five text segments, as most definitions and text segments were quite clear-cut). If text segments referred to more than one subcode, they were placed in each of the relevant categories. Throughout the process of coding the causes, consequences, and potential responses to GCC, we considered differences among materials from different subject areas (social studies, science, and multiple subject) and in the different conceptual categories (adherent, hesitant, and dissenting). Below we summarize our overall findings, including which 
curricula fit into these conceptual categories and the differences in how they portray the major dimensions of GCC.

\section{5 | FINDINGS}

Overall, based on our analyses of how the curricula portray GCC, curricular materials about GCC fit into three categories: adherent, hesitant, and dissenting. Materials in the three categories differ in their portrayal of (1) the cause of GCC, (2) the consequences of GCC, and (3) how society might respond to GCC. Below we provide details and examples to illustrate each of these major differences.

\section{1 | Competing conceptions about the cause of GCC}

In this section, we clarify how adherent, hesitant, and dissenting curricula in our study portray the causes of GCC. These findings from the three different categories of curricula reveal a wide variety of portrayals of the cause of GCC. First, our analyses of text segments indicate that six of the eight sets of supplemental materials and three of the nine textbooks were adherent, portraying the cause of GCC as a closed question, with human activity playing a primary role. These curricula supported the general conclusions of the IPCC's 4th Assessment Report. For example, an essay in the National Wildlife Federation's AIT in the Classroom (2008) curriculum reads:

For a long time, people did not agree about whether global warming was really happening and, if it was, whether people were to blame or not. Now that has changed. There is now irrefutable evidence that the Earth's climate is changing 
and global temperatures are rising. Consensus has emerged among the majority of scientists and experts (p. 17).

Other adherent materials, like Deliberating in a Democracy: Global Climate Change (2009), make no reference to questions about the validity of the science and thus imply that the validity of the science is not an open question. Instead, this set of materials takes for granted the anthropogenic causes of global warming.

Curricula in a second category were labeled hesitant because they portray the question of anthropogenic climate change as open, suggesting that scientists are still uncertain whether human activity or natural phenomena cause GCC. None of the supplemental materials fall into the hesitant category, but six of the nine textbooks do. For example, in Glencoe's Earth Science (2009), students read that "Based on available temperature data, many scientists agree that global warming is occurring. They disagree, however, about what is causing this warming” (p. 394). Similarly, the authors of another Glencoe textbook, World Geography (2012), write:

Scientists do not all agree on the nature of global warming and its effects. Some claim that a natural cycle, not human activity, is causing rising temperatures. Others claim that the evidence for global warming is inconclusive and that it is too early to forecast future effects (p.53).

These materials communicate to their readers that human activities may not be responsible for GCC.

Finally, two sets of supplemental materials, but none of the textbooks, are examples of dissenting curricula. These curricula are similar to the adherent curricula in that they treat the cause of GCC as a closed question, but they communicate that the causes of GCC are natural 
phenomena, such as oscillations in the amount of radiation emitted from the sun. Similarly, dissenting curricula take a strong stance against the notion of scientific consensus regarding GCC. A message repeatedly conveyed in Understanding Climate Change (2009) is that scientists widely disagree with the conclusions of the IPCC. Teachers and students using this set of materials read that "[H]ypotheses about climate change abound, and despite the popular media conception of consensus, the issues are far from settled" (p. 3) and "[M]any scientists who once thought human activities caused climate change are no longer certain that that is the case" (p. 49).

These dissenting materials also imply that the IPCC's conclusions should not be trusted. For instance, in the DVD that accompanies Unstoppable Solar Cycles (2008), Dr. Willie Soon ${ }^{7}$, one of two climate science "experts" interviewed in the video, explains:

It's very, very difficult, in my opinion, to try to insist and suggest that carbon dioxide, even as of today when we emit this carbon dioxide, is going to drive the climate system. This is a complete false picture and there is no such scientific basis to support that.

An example from a lesson entitled "Data Mining" in the Understanding Climate Change (2009) curriculum is equally overt. In this lesson students are presented with what the media have dubbed "the hockey stick graph" due to the shape of the connected data points. Those who communicate about climate science commonly use this graph as a dramatic image of the strong correlation between human-induced greenhouse gases and rising global temperatures. In this lesson, though, the purpose is not to provide empirical evidence for human-caused global

\footnotetext{
${ }^{7}$ Work by Dr. Soon, an astrophysicist who has received over one million US dollars in funding from large energy companies (Gardner, 2011), is regularly quoted by organizations that promote the doubtful or dismissive perspectives of global climate change.
} 
warming. Rather, the stated purpose of this lesson is "to help students better understand how data are presented and how data are used to test a hypothesis. Students will learn that data can be misused, whether by a selective use of data subsets or by graphing and charting tricks" (p. 69). The authors of Understanding Climate Change imply that the data depicted on this graph, despite being vetted repeatedly by climate scientists, is highly suspect.

\subsection{Competing conceptions about the seriousness of GCC}

\subsection{1 | Differing portrayals of the consequences of GCC}

Another major difference among the adherent, hesitant, and dissenting curricula is how they convey the specific problems related to GCC. The 2007 IPCC Synthesis Report presents evidence for two broad categories of effects from our changing climate: one labeled "Climate Change" that includes rising temperatures and sea levels, changing precipitation patterns, and more extreme weather events; and a second set of effects labeled "Impacts and Vulnerability," which includes aspects of the built and natural world impacted by climate change, such as ecosystems and food security. Most adherent curricula convey content about each climatic change and set of effects, but the hesitant curricula only describe some of these. Meanwhile, the dissenting curricula provide scant content about either changes to the climate or the impacts these changes will have on the built and natural environments (see Table 3).

Adherent curricula depict the problems of GCC as widespread. For example, multiple lessons in the Will Steger Foundation's Global Warming 101 (2009) ask students to explore the impacts of GCC on a host of geographically diverse places. One activity within this curriculum asks students to compare and contrast problems related to GCC in Iowa, Norway, the Republic of Chad, the Amazon River basin, southern California, and the Maldives. An Inconvenient Truth 
(AIT), the documentary film anchoring An Inconvenient Truth in the Classroom (2008) materials, refers to a number of specific regions, cities, and countries, including some within the United States, to illustrate the pervasiveness of climate change. Apropos to its title, Climate Change: A Wisconsin Activity Guide (2009) sets the stage for a Wisconsin-focused exploration of GCC on its introductory page: "Increasingly policy makers and citizens, including students, are discussing and grappling with serious climate change issues facing Wisconsin and the planet" (p. 3).

TABLE 3 | Climatic Changes and Impacts Noted in Adherent, Hesitant, and Dissenting Curricula

\begin{tabular}{|c|c|c|c|c|c|c|c|c|c|c|}
\hline \multirow[b]{2}{*}{$\begin{array}{l}\text { Conceptual Category and } \\
\text { Title }\end{array}$} & \multicolumn{4}{|c|}{ Changes to climate } & \multicolumn{6}{|c|}{ Impacts and vulnerabilities } \\
\hline & temp & precip & sea level & $\begin{array}{l}\text { extreme } \\
\text { events }\end{array}$ & $\begin{array}{l}\text { food } \\
\text { security }\end{array}$ & $\begin{array}{l}\text { water } \\
\text { security }\end{array}$ & $\begin{array}{l}\text { ecosystems- } \\
\text { physical } \\
\text { features }\end{array}$ & $\begin{array}{l}\text { ecosystems- } \\
\text { flora/fauna }\end{array}$ & society & $\begin{array}{l}\text { human } \\
\text { health }\end{array}$ \\
\hline \multicolumn{11}{|l|}{ Adherent Curricula } \\
\hline $\begin{array}{l}\text { Living in the Environment, } \\
16^{\text {th }} E d .^{b}\end{array}$ & 2:N-FI & 2:NI-CFI & $\begin{array}{l}\text { 3:NSI- } \\
\text { CFI }\end{array}$ & 3:NI-CFI & 3:SI-CFI & 2:SI-FI & 4:NSI-CFI & 4:NSI-CFI & 4:SI-CFI & 4:NSI-FI \\
\hline $\begin{array}{l}\text { An Inconvenient Truth } \\
\text { in the Classroom }^{c}\end{array}$ & 4:NSI-I & 3:NI-CFI & 3:SI-CI & 4:NI-CFI & $1: \mathrm{S}-\mathrm{C}$ & 2:SI-CF & 4:NF-CFI & 4:NI-CFI & 4:NI-CF & $3: \mathrm{N}-\mathrm{CF}$ \\
\hline $\begin{array}{l}\text { Climate Change: A } \\
\text { Wisconsin Activity Guide } \\
\text { abcd }\end{array}$ & $1:$ NI-I & 2:I-CI & 1:S-I & $1: \mathrm{I}-\mathrm{I}$ & 2:SI-CFI & $1: \mathrm{I}-\mathrm{FI}$ & $1: \mathrm{NI}-\mathrm{CI}$ & $4: \mathrm{NI}-\mathrm{CI}$ & 2:NI-CFI & $1: \mathrm{I}-\mathrm{F}$ \\
\hline $\begin{array}{l}\text { Climate Change: } \\
\text { Connections and Solutions } \\
a b c\end{array}$ & 2:NSI-FI & 4:NI-FI & 3:NS-FI & 3:NI-CFI & 3:NI-FI & $1: \mathrm{NI}-\mathrm{FI}$ & 0 & 4:NI-FI & 0 & 0 \\
\hline GlobalWarming101 abcd & 3:NS-FI & 3:NI-FI & 3:NSI-I & $1: I-F I$ & $1: \mathrm{I}-\mathrm{I}$ & $1: \mathrm{I}-\mathrm{I}$ & 2:SI-FI & $4: \mathrm{NI}-\mathrm{FI}$ & 4:NSI-FI & 2:NI-FI \\
\hline $\begin{array}{l}\text { Deliberating in a } \\
\text { Democracy: Global Climate } \\
\text { Change }^{a}\end{array}$ & $1: I-I$ & $1: I-I$ & 0 & $1: \mathrm{I}-\mathrm{I}$ & $1: I-I$ & $1: \mathrm{I}-\mathrm{I}$ & 1:NI-FI & 2:SI-FI & 1:I-FI & $1: \mathrm{I}-\mathrm{I}$ \\
\hline $\begin{array}{l}\text { Choices: Global } \\
\text { Environmental Problems }{ }^{a}\end{array}$ & 2:NSI-I & $1: \mathrm{I}-\mathrm{I}$ & 1:NS-FI & 2:NI-CFI & $1: I-I$ & $1: I-I$ & 3:I-FI & 3:NI-I & 3:NI-CFI & $1: \mathrm{I}-\mathrm{I}$ \\
\hline $\begin{array}{l}\text { Human Geography: } \\
\text { Landscapes of Human } \\
\text { Activity, 11th Ed a }\end{array}$ & 2:N-FI & 1:NI-CI & 2:NS-I & $1: I-I$ & 3:I-CF & $1: \mathrm{I}-\mathrm{C}$ & 3:NSI-FI & 1:NS-I & 2:NI-FI & 0 \\
\hline $\begin{array}{l}\text { McDougal Littell Modern } \\
\text { World History: } \\
\text { Patterns of Interaction }{ }^{a}\end{array}$ & $1: \mathrm{N}-\mathrm{I}$ & $1: I-I$ & $1: I-I$ & 0 & 0 & 0 & $1: \mathrm{I}-\mathrm{I}$ & 0 & 0 & 0 \\
\hline
\end{tabular}


TABLE 3 cont. | Climatic Changes and Impacts Noted in Adherent, Hesitant, and Dissenting Curricula

Changes to climate

\begin{tabular}{|c|c|c|c|c|c|c|c|c|c|c|}
\hline $\begin{array}{l}\text { Conceptual Category } \\
\text { and Title }\end{array}$ & temp & precip & $\begin{array}{l}\text { sea } \\
\text { level }\end{array}$ & $\begin{array}{l}\text { extreme } \\
\text { events }\end{array}$ & $\begin{array}{c}\text { food } \\
\text { security }\end{array}$ & $\begin{array}{c}\text { water } \\
\text { security }\end{array}$ & $\begin{array}{c}\text { ecosystems- } \\
\text { physical } \\
\text { features }\end{array}$ & $\begin{array}{l}\text { ecosystems- } \\
\text { flora/fauna }\end{array}$ & society & $\begin{array}{l}\text { human } \\
\text { health }\end{array}$ \\
\hline \multicolumn{11}{|l|}{ Hesitant curricula } \\
\hline $\begin{array}{l}\text { Glencoe Earth } \\
\text { Science }{ }^{b}\end{array}$ & 2:NS-FI & 0 & 3:NI-I & $1: \mathrm{IN}-\mathrm{IC}$ & 0 & 0 & 3:NI-FI & 0 & $\begin{array}{l}3: \mathrm{NI}- \\
\text { CFI }\end{array}$ & 0 \\
\hline $\begin{array}{l}\text { Prentice Hall Earth } \\
\text { Science }^{b}\end{array}$ & 2:NS-CI & 2:NI-CI & $1: I-I$ & $1: \mathrm{IN}-\mathrm{IC}$ & 0 & 0 & $1: \mathrm{I}-\mathrm{I}$ & 0 & 0 & 0 \\
\hline $\begin{array}{l}\text { Prentice Hall } \\
\text { Biology }^{b}\end{array}$ & 1:NS-I & $1: I-I$ & $1: \mathrm{I}-\mathrm{I}$ & 0 & $1: \mathrm{I}-\mathrm{I}$ & 0 & 1:NSI-FI & $1: \mathrm{I}-\mathrm{I}$ & $1: I-I$ & 0 \\
\hline $\begin{array}{l}\text { Glencoe World } \\
\text { Geography }\end{array}$ & 2:NS-I & $1: \mathrm{I}-\mathrm{I}$ & $1: I-F I$ & $2: \mathrm{IN}-\mathrm{IF}$ & 0 & 0 & 2:NI-FI & $1:$ NI-FI & $1: \mathrm{NI}-\mathrm{F}$ & 0 \\
\hline \multicolumn{11}{|l|}{ Dissenting curricula } \\
\hline $\begin{array}{l}\text { Understanding } \\
\text { Climate Change }\end{array}$ & 2:NI-CI & 0 & 0 & $1: \mathrm{N}-\mathrm{C}$ & 0 & 0 & 0 & 0 & 0 & 0 \\
\hline $\begin{array}{l}\text { Unstoppable Solar } \\
\text { Cycles }\end{array}$ & $1: \mathrm{N}-\mathrm{I}$ & 0 & 0 & 0 & 0 & 0 & 0 & 0 & 0 & 0 \\
\hline
\end{tabular}

Note.

${ }^{a}$ References social studies education standards ${ }^{b}$ References science education standards ${ }^{c}$ References Environmental Education Guidelines for Excellence

${ }^{d}$ References Mathematics, English-Language Arts, and/or Art-Design standards

$1=1-5$ sentences $2=6-10$ sentences $3=11-20$ sentences $4=21+$ sentences

$\mathrm{N}=$ now/present, $\mathrm{S}=$ soon/near future, $\mathrm{I}=$ indeterminate; $\mathrm{C}=$ close to $\mathrm{US}, \mathrm{F}=$ far from $\mathrm{US}, \mathrm{I}=$ indeterminate

The preponderance of evidence from climate science suggests that the adherent materials challenges for the entire planet. The two AP-level textbooks, Human Geography: Landscapes of

Human Activities (2010) and Living in the Environment (2009), stand apart from the other

adherent curricula in the concerned tone they strike. For instance, the authors of Human 
At worst, severe and pervasive [climate] changes could result in a total restructuring of the landscapes of culture and the balances of human-environmental relationships presently established. Nothing, from population distributions to the relative strength of countries, would ever be quite the same again (p. 426).

Similarly, Living in the Environment warns its readers that "Many scientists argue that our most urgent priority is to do all we can to avoid any and all irreversible climate or ecological tipping points. Once we reach such a point, there is no going back. It is like going over a cliff' (p. 510, emphasis in original). To drive the point home, the authors connect climate change to deepseated fears undergirding U.S. society for decades when they note that a military think tank equates GCC's consequences with those of nuclear war, explaining that some experts view the threat of climate change as "more serious even than the threat of terrorism" (p. 506).

In addition, adherent curricula position the impacts of GCC as underway or imminent. Climate Change: Connections and Solutions (2007), for instance, mentions that the "Eleven years between 1995 and 2006 are among the 12 hottest years recorded since 1850" (p. 97) and that "Wind and precipitation patterns have changed in many regions during the past century" (p. 98). Likewise, the Wisconsin DNR's A Wisconsin Activity Guide (2009) notes, "Many parts of Africa already suffer from water and food shortages and severe economic and social challenges. Climate change is likely to greatly exacerbate these conditions" (p. 7).

The hesitant curricula, on the other hand, provide little information about the impacts and vulnerability related to climate change. Although they do mention rising temperatures, changes to sea levels, and changes to precipitation patterns, their coverage of these issues is often brief. For instance, whereas Glencoe's World Geography (2012) contains 57 sentences related to GCC and its effects spread over six different sections of the text, Prentice Hall's World Geography 
(2009) includes just 19 sentences spaced over four sections. In contrast, the AP-level texts, both examples of adherent curriculum, allow more space for the topic to provide details about GCC's impacts and vulnerability: 119 sentences in Human Geography: Landscapes of Human Activities (2010) and 696 sentences in Living in the Environment (2009).

Aside from these quantitative differences between the hesitant and adherent curricula, the former convey a limited scope of the problems associated with GCC. Moreover, the way this content is presented tends to nullify any sense of urgency to respond to GCC. For example, although rising sea levels could inundate areas inhabited by hundreds of millions of people, Glencoe's World Geography (2012) merely informs students "that the increase in temperature will cause glaciers and ice caps to melt, raising the level of the world's oceans" (p. 110). Only one other sentence, 223 pages later, returns to the problem of rising sea levels: "A warmer climate will melt polar ice caps and mountain glaciers, causing ocean levels to rise and submerge coastal areas” (p. 333). Moreover, several hesitant materials geographically distance global warming's impacts from the continental United States, instead focusing on Arctic climes. In a section specifically focused on how the people of North America interact with the environment, World Geography mentions only the effects of global warming as a challenge for Alaska and northern Canada. In addition, hesitant materials are peppered with vague references to the timing of climate change's effects. For example, Holt McDougal's Earth Science (2009) includes the following content about changes in precipitation patterns:

An increase in global temperature can lead to an increase in evaporation. Increased evaporation could cause some areas to become drier than they are now. Some plants and animals would not be able to live in these drier conditions. An increase in evaporation in other areas could cause crops to suffer damage (p. 679). 
Thus, the hesitant curricula position the problems associated with GCC as much less immediate or geographically close than the adherent curricula do. Meanwhile, in the dissenting curricula, climatic changes are referred to dismissively, and the only mention of any impact or vulnerability occurs briefly on the last page of the 109-page Understanding Climate Change (2009) curriculum (and suggests that food security might be a problem in the future).

\subsection{2 | Differing portrayals of anticipated temperature changes}

The curricula in each category also differ in their portrayals of how much average global temperatures are expected to change over the next several decades, which the IPCC in 2007 estimated to be between 3.2 and 7.2 degrees Fahrenheit (see Table 4). Adherent materials, with the exception of McGraw-Hill's Human Geography (2010), offer predictions skewed toward the high end of the IPCC's predicted range whereas hesitant curricula provide predictions more in line with the IPCC's best estimate. For example, adherent curriculum An Inconvenient Truth in the Classroom (2008) states the range of temperature changes as between 4 and 11 degrees Fahrenheit, and Living in the Environment (2009) suggests that global temperatures will shift by 3.6 to 8.1 degrees. On the other hand, the hesitant textbook by Holt McDougal, Earth Science (2010), places the range at 3.6 to 7.2 degrees Fahrenheit. Whereas one dissenting curriculum, Unstoppable Solar Cycles (2008), makes no prediction of temperature changes, the other dissenting curriculum presents a notably broad range, indicating future temperature changes between 1.5 and 11.5 degrees.

How curricula portray the seriousness of the problems associated with GCC could influence how students perceive the problem. Despite the most recent climate science indicating that climate change is well underway and is affecting the entire planet, many portrayals of GCC in the curricula we analyzed suggest a degree of distance - both temporal and geographic- 
between students and GCC. Students enrolled in courses using the dissenting or hesitant curricula may be led to believe that GCC is not a serious, current, or imminent problem.

TABLE 4 | Predicted Global Temperature Increases in Adherent, Hesitant, and Dissenting Curricula

\begin{tabular}{|c|c|c|c|}
\hline $\begin{array}{l}\text { Adherent } \\
\text { Curricula }\end{array}$ & $\begin{array}{l}\text { Predictions of } \\
\text { temperature rise }\end{array}$ & $\begin{array}{l}\text { Hesitant and Dissenting } \\
\text { Curricula }\end{array}$ & $\begin{array}{l}\text { Predictions of } \\
\text { temperature rise }\end{array}$ \\
\hline Living in the Environment, 16th Ed. & $3.6-8.1^{\circ} \mathrm{F}$ & Glencoe Earth Science & $1.8-6.3^{\circ} \mathrm{F}$ \\
\hline $\begin{array}{l}\text { An Inconvenient Truth in the } \\
\text { Classroom }\end{array}$ & $4-11^{\circ} \mathrm{F}$ & Holt McDougal Earth Science & $3.6-7.2^{\circ} \mathrm{F}$ \\
\hline $\begin{array}{l}\text { Climate Change: Connection and } \\
\text { Solutions }\end{array}$ & $2.5-10.4^{\circ} \mathrm{F}$ & Prentice Hall Earth Science & $>9^{\circ} \mathrm{F}$ \\
\hline $\begin{array}{l}\text { Deliberating in a Democracy: } \\
\text { Global Climate Change }\end{array}$ & no prediction & Prentice Hall Biology & $\begin{array}{l}3.2-6.5^{\circ} \mathrm{F} \text { by } \\
2050\end{array}$ \\
\hline Global Environmental Problems & $2-11^{\circ} \mathrm{F}$ & Glencoe World Geography & $3.2-7.2^{\circ} \mathrm{F}$ \\
\hline Global Warming 101 & $2.5-10.4^{\circ} \mathrm{F}$ & $\begin{array}{l}\text { Prentice Hall World } \\
\text { Geography }\end{array}$ & no prediction \\
\hline $\begin{array}{l}\text { Climate Change: A Wisconsin } \\
\text { Activity Guide }\end{array}$ & no prediction & Understanding Climate Change & $1.3-11.5^{\circ} \mathrm{F}$ \\
\hline $\begin{array}{l}\text { Human Geography: Landscapes of } \\
\text { Human Activity, 11th Ed. }\end{array}$ & $3.2-7.2^{\circ} \mathrm{F}$ & Unstoppable Solar Cycles & no prediction \\
\hline $\begin{array}{l}\text { McDougal Littell Modern World } \\
\text { History: Patterns of Interaction }\end{array}$ & no prediction & & \\
\hline \multicolumn{4}{|c|}{ Intergovernmental Panel on Climate Change Synthesis Report (2007) } \\
\hline
\end{tabular}

Note. Unless otherwise noted the predictions are for the span of time ending in 2100 . The temperature increases represent the rise in temperature above the 1980-1989 global average temperature.

$\stackrel{a}{=}$ These numbers are the range of the "best estimate" predictions of global average temperature considering the six emission scenarios included in the IPCC's 2007 Synthesis Report. The likely rise in temperature using the range of all emission scenarios noted in the IPCC report is $2-11.5^{\circ} \mathrm{F}$. 


\section{3 | Competing conceptions over how to respond to GCC}

\subsubsection{How curricula portray options for responding to GCC}

Scientists who study GCC have identified three broad sets of strategies to respond to the problem: mitigation, adaptation (e.g., IPCC, 2007, 2014), and geo-engineering (e.g., Launder \& Thompson, 2010). First, to diminish or halt some of the resulting negative outcomes of climate change, mitigation strategies center on reducing the amount of greenhouse gases in the atmosphere through, for example, energy conservation or international shifts to "green" energy. Second, adaptation strategies, aimed at preparing societies for living with a rapidly changing climate, include communities building walls to keep out the rising seas and the development of infrastructure that can withstand increasingly intense storms. Finally, geo-engineering refers to large-scale climate control projects designed to influence how the physical systems of the Earth operate in order to stem major disruptions in climate. Seeding the oceans with iron to encourage the growth of carbon dioxide-consuming algae is one example. Although responding to GCC and its effects may require a combination of mitigation, adaptation, and geo-engineering, the curricula analyzed in this study present a limited range of options—-focusing primarily on mitigation.

Indeed, adaptation was barely mentioned in all 17 sources analyzed in this study. Furthermore, only the AP Environmental Science textbook Living in the Environment (2009) mentions geo-engineering as a possible course of action, though the authors make it clear that geo-engineering is not a particularly wise option to pursue. The text discusses several large-scale geo-engineering schemes, including injecting massive amounts of sunlight-reflecting chemicals 
into the stratosphere and covering glaciers to inhibit their melting. However, the authors ultimately argue "the major problem with these techno fixes is that if they ever fail while we continue adding CO2 to the atmosphere, the rebound effects could be calamitous" (p. 518).

GCC curricula overwhelmingly privilege mitigation strategies at the expense of having students consider adaptation and geo-engineering as viable responses. Every curriculum in our analysis but one (Unstoppable Solar Cycles) noted at least one mitigation strategy, with green technology and energy conservation (by both individuals and groups) as the most frequently mentioned strategies, followed by using laws and regulations to curb emissions (see Table 5). Deploying green technologies, a response brought up in 12 of the 17 curricula, includes actions such as developing alternative and renewable energy sources and employing carbon capture and storage (CCS) technology in power plants and other large-scale emitters of greenhouse gases. For example, the Wisconsin Climate Change Activity Guide (2009) states:

Using alternative energy sources that emit no or few greenhouse gases will allow people to shift to a new way of living that better protects the global climate. In addition to solar, wind, and hydroelectric alternative energy sources, biomass, and biofuel are receiving increased attention (p. 8).

Energy conservation, also mentioned in 12 of the 17 data sources, refers to a wide range of actions. Some mentions of conservation are general as exemplified in Prentice Hall's Biology, which simply states, "People can make wise choices in the use and conservation of resources" (p. 160). A number of other materials, including The Will Steger Foundation's Global Warming 101 (2009), describe specific strategies to conserve energy like "turn down your water heater thermostat" or "whenever possible, walk, bike, carpool, or use mass transit" (p. 19). 
TABLE 5 | Mitigation Strategies in the Adherent and Hesitant Science, Interdisciplinary, and Social Studies Materials ${ }^{a}$

\begin{tabular}{|c|c|c|c|c|c|c|}
\hline \multirow[b]{2}{*}{ Curricula by core content area } & \multicolumn{6}{|c|}{ Mitigation strategies } \\
\hline & $\begin{array}{l}\text { Kyoto } \\
\text { Protocol }\end{array}$ & $\begin{array}{l}\text { cap-and- } \\
\text { trade }\end{array}$ & $\begin{array}{l}\text { laws and } \\
\text { regs. }\end{array}$ & green tech. & $\begin{array}{l}\text { energy } \\
\text { conserv. }\end{array}$ & $\begin{array}{l}\text { individual } \\
\text { action (other } \\
\text { than } \\
\text { consery) }\end{array}$ \\
\hline \multicolumn{7}{|l|}{ Science materials } \\
\hline Living in the Environment, $16^{\text {th }} \mathrm{Ed} .^{++}$ & 3 & 4 & 4 & 4 & 4 & 1 \\
\hline Glencoe Earth Science $^{+}$ & 0 & 0 & 0 & 4 & 4 & 0 \\
\hline Holt McDougal Earth Science ${ }^{+}$ & 0 & 0 & 1 & 1 & 2 & 1 \\
\hline Prentice Hall Earth Science $^{+}$ & 0 & 0 & 0 & 4 & 3 & 0 \\
\hline Prentice Hall Biology $y^{+}$ & 0 & 0 & 0 & 0 & 2 & 0 \\
\hline \multicolumn{7}{|l|}{ Interdisciplinary materials } \\
\hline $\begin{array}{l}\text { Climate Change: Connections and } \\
\text { Solutions }^{++}\end{array}$ & 4 & 4 & 1 & 4 & 4 & 3 \\
\hline $\begin{array}{l}\text { An Inconvenient Truth in the } \\
\text { Classroom }^{++}\end{array}$ & 3 & 0 & 3 & 3 & 3 & 2 \\
\hline $\begin{array}{l}\text { Climate Change: A Wisconsin Activity } \\
\text { Guide }^{++}\end{array}$ & 0 & 0 & 0 & 4 & 2 & 1 \\
\hline Global Warming $101^{++}$ & 0 & 0 & 1 & 1 & 1 & 1 \\
\hline \multicolumn{7}{|l|}{ Social Studies materials } \\
\hline $\begin{array}{l}\text { Choices: Global Environmental } \\
\text { Problems }^{++}\end{array}$ & 4 & 3 & 4 & 4 & 1 & 1 \\
\hline $\begin{array}{l}\text { Deliberating in a Democracy: Global } \\
\text { Climate Change }^{++}\end{array}$ & 1 & 3 & 1 & 0 & 1 & 1 \\
\hline $\begin{array}{l}\text { McDougal Littelh Modern World } \\
\text { History: Patterns of Interaction }\end{array}$ & 0 & 0 & 2 & 1 & 0 & 0 \\
\hline $\begin{array}{l}\text { Human Geography: Landscapes of } \\
\text { Human Activity, } 11^{\text {th }} \mathrm{Ed}^{++}\end{array}$ & 2 & 1 & 1 & 2 & 1 & 2 \\
\hline Prentice Hall World Geography ${ }^{+}$ & 0 & 0 & 1 & 0 & 0 & 0 \\
\hline Glencoe World Geography ${ }^{+}$ & 1 & 0 & 2 & 2 & 0 & 0 \\
\hline
\end{tabular}

Note. $\stackrel{a}{=}$ Whether a source was considered social studies, interdisciplinary, or science was determined by the obvious content area the source addressed (i.e. Glencoe Earth Science) and/or the content area(s) explicitly referred to within the lesson plans or resources overviews. Those resources that referred to content areas beyond the National Science Education Standards or the National Curriculum Standards for Social Studies were considered interdisciplinary. ${ }^{++}$Adherent curricula, ${ }^{+}$Hesitant curricula; $1=1-5$ sentences, $2=6-10$ sentences, $3=11-20$ sentences, $4=21+$ sentences 
Even Understanding Climate Change (2009), a dissenting curriculum, mentions three mitigation strategies, but in the process, it subtly advocates against such strategies. For instance, in one lesson plan, the teacher is directed to identify climate change as a low global priority and to explain cap-and-trade systems and carbon taxation, two policies designed to mitigate greenhouse gas emissions, in a negative light: "Discuss with students the costs of emissions regulations. Stricter emissions regulations would increase the price of most products" (p. 103). Finally, students are sent to work in small groups with their task being to "design a policy that will address your constituents' concerns about climate change." The constituents for students to consider include taxpayers ("none of whom want their tax dollars to be wasted"), oil companies ("concerned about their public image and higher energy costs"), alternative energy suppliers ("that want subsidies to lower the higher costs of their products"), environmental groups ("that advocate dramatic reductions in $\mathrm{CO}_{2}$, irrespective of the costs"), and low-income households

("that cannot afford higher energy prices"). The descriptions of each stakeholder's concern—-that the economic bottom line is of primary importance to any policy solution — would likely limit students' consideration of a robust range of policies for responding to GCC.

\subsection{2 | How curricula portray who governs climate}

In addition to explaining how we might respond to GCC, the curricula analyzed for this study convey differing messages about who governs climate — and thus, how the problem should be addressed. Specifically, there are differences in how the curricula situate the government, industry, and individuals as potential agents in responding to global warming. Two noteworthy patterns emerge from the data.

First, whereas dissenting curricula suggest that natural cycles are the primary forces of climate change (and therefore no action is needed to "fix" the problem), adherent and hesitant 
curricula communicate the importance of government and individual action to address the problem. For instance, An Inconvenient Truth in the Classroom (2008) imparts to its readers:

The important thing to remember is that humans have caused this problem, so humans should be able to fix it...But remember there is no single solution; it is going to be a combination of people and governments working together to implement a range of strategies to tackle this problem (p.21).

These materials offer some examples of industry proactively responding to global warming, but more common are examples which position the private sector as reacting to pressure from individuals and governments. For example, Climate Change: Connections and Solutions (2007), advises students that by "being informed and demanding more efficient, climate-friendly products when you go shopping, consumers like you will influence manufacturers to care more about their effects on the climate" (p. 108).

At the same time the adherent and hesitant curricula advance the government and individuals as key drivers leading mitigation efforts, the dissenting curricula conclude that nothing need be done in response to global warming. In Unstoppable Solar Cycles (2008), among the 21 questions recommended for class discussion or homework are:

If we would have to give up all of our modern conveniences and start living like people in Europe and America did 200 years ago — or like people in many developing countries do today_ _ just to possibly slightly slow the rate of warming in the distant future, would it still be worth the effort? How and by whom should this be decided?.. Assuming we could prevent global warming, is this the only goal that matters? Are there other goalsindividual freedom and economic prosperity, for example — that should be factored into 
any decision about how to respond to global warming? (p. 6-7, emphasis in original)

Dissenting curricula communicate caution toward any government intervention in the matter. According to the authors of Understanding Climate Change (2009) students should come away from the final two lessons understanding that "It is often believed that governments can solve our environmental and social problems. It is important to understand, however, that even government resources are limited" (p. 95). In short, dissenting curricula suggest that little can be done to address GCC.

The second major pattern emerging from this portion of the analysis is about the differences between the content areas regarding who governs the climate. Whereas social studies-specific curricula primarily note the importance of governments in implementing strategies to address GCC, the nonsocial studies curricula (which address standards in various subjects) position actions of individuals as paramount to addressing the problem. This difference is most striking when comparing the science textbooks to the social studies-focused curricula. As Table 5 shows, only one out of five science textbooks, Living in the Environment (2009), mentions the Kyoto Protocol and how other laws and regulations could mitigate carbon emissions. Conversely, all social studies-focused materials mention laws and regulations as tools to mitigate greenhouse gas emissions, and four out of six mention the Kyoto Protocol. For example, McDougal Littell's Modern World History: Patterns of Interaction (2009) points out that "Government action and stronger regulations may provide solutions to the world's environmental problems in the 21 st century" (p. 682).

Indeed some social studies textbooks position governments as central to responding to climate change even for those actions in which the private sector could play and often does play a significant role. For instance, in Glencoe's World Geography (2012), students read “[S]ome 
countries are developing alternative fuels. For example, Sweden introduced the first biogaspowered passenger train" (p. 334, emphasis added) and "Governments offer subsidies and put pressure on utility companies to limit emissions and include renewable energy sources in their future plans" (p. 176, emphasis added). In the two sets of social studies-specific supplemental materials, readers encounter lessons exclusively centered on potential U.S. environmental policies. For instance, one Deliberating in a Democracy: Global Climate Change (2009) lesson asks students to deliberate over this question: "Should our democracy adopt a cap-and-trade system to limit greenhouse gas emissions?" Similarly, the capstone activity featured in the Global Environmental Problems curriculum (2009) includes a role-play activity in which small groups of students develop compelling arguments supporting one of four potential U.S. environmental policy options.

Whereas government initiatives to regulate emissions or develop environmentally friendly technology are the foci of responses within social studies curricula, the nonsocial studies curricula call attention to the importance of individual action to mitigate GCC. Individual actions noted within the nonsocial studies curricula fall into one of five categories: changing personal habits (e.g., eating less meat), educating others, consumer action (e.g., buying locally grown food), political action (primarily through writing elected officials), and, by far the most prevalent category, taking direct actions to conserve energy. Most nonsocial studies texts in our analysis commit at least 10 sentences to individual energy conservation strategies, and three contain more than 20 sentences about this. On the other hand, none of the social studies-focused materials have more than five sentences about such mitigation approaches, and three neglect to mention such strategies at all. 
One general message in nonsocial studies materials is that taking steps to personally conserve energy can be easy and sufficient for responding to GCC. For example, Glencoe's Earth Science textbook (2009) offers the following for students to consider:

Individuals reduce the amount of carbon dioxide emitted to the atmosphere by conserving energy, which reduces fossil fuel consumption. Some easy ways to conserve energy include turning off electrical appliances and lights when not in use, turning down thermostats in the winter, recycling, and reducing the use of combustion engines, such as those in cars and lawn mowers (p. 395).

Likewise, Holt McDougal's Earth Science (2010) textbook uses a section subtitled "Individual Efforts" to convey the following:

Each individual person can also help to reduce pollution that is caused by the burning of fossil fuels, such as running automobiles and using electricity...humans can have a significant effect on pollution rates by turning lights off when they are not in use, turning down the heat in the winter and by reducing air conditioner use in the summer (p. 620).

Global Warming 101 (2009), Connections and Solutions (2007), and AITC (2008) each contain lesson plans calling for students to calculate their carbon footprint and then identify ways they can personally reduce the amount of greenhouse gases they emit. And one student handout in Global Warming 101 listing ways to reduce one's carbon footprint is entitled, "20 Simple Steps to Reduce Global Warming.” The authors of Prentice Hall's Biology (2008) rhetorically ask readers "Is there any way that people can help maintain the health of the biosphere without drastically changing their lifestyles? The answer is yes. People can make wise choices in the use 
and conservation of resources" (p. 160). Although these actions may be appropriate and helpful, focusing on them exclusively could limit the scope of what students might do. Overall, the differences in how curricula with different subject area foci portray who governs climate are notable and could shape what students in certain courses learn about how to respond to climate change.

\section{6 | DISCUSSION}

This study's findings provide insights that will be useful to educators, researchers, and others concerned about preparing young people to address our environmental challenges. Whereas prior research explores how curricula depict the range of scientific topics related to GCC (Choi et al., 2010) or how materials in countries outside the United States communicate about the issue (Bagalo-Simo, 2013; Chambers \& Rowell, 2005), this is the first research that examines how several U.S. high school-level curricula portray various dimensions of the causes, consequences, and potential responses to GCC. Although the curricula we examined were published between 2007 and 2012, some of these materials are likely still in use (UNESCO, 2017; Zinth, 2005). Furthermore, our analyses of which GCC issues are featured and how they are portrayed highlight notable variations in curricular content and provide a useful foundation for future research.

\section{1 | Scholarly contribution}

Overall, this analysis found that many widely used curricula in the United States published in the early 2000s obscure GCC's human causes and downplay its consequences. Whereas two of seventeen curricula analyzed in this study deny that climate change is caused by human activity, six others raise doubts about the scientific consensus on this issue. These dissenting and hesitant 
curricula include few details about not only climatic changes but also the variety of GCC's impacts, such as food and water insecurity (see Table 3). Of the textbooks and supplemental materials that do explore the consequences of GCC, several indicate that extreme weather events and flooding will be problems only on other continents and mostly in the relatively distant future. Such portrayals suggest to students that they need not be concerned about GCC, which could make them less likely to take action to address it (Herman, 2014; Roser-Renouf et al., 2014). Meanwhile, whereas some adherent materials portray the full range of climatic changes and impacts, these curricula occasionally exaggerate near-term temperature changes (see Table 4).

Furthermore, even the curricula that portray anthropogenic climate change as a settled scientific issue present limited options for addressing it. Many scientists consider adaptation strategies vital for the sustainability of human societies (IPCC, 2007, 2014; Reidsma, Ewert, Lansink, \& Leemans, 2010), but such strategies were almost entirely absent from all 17 curricula. Geo-engineering, which some researchers consider a viable response option (Macnaghten \& Szerszynski, 2017), was also barely mentioned at all in any curricula. Whereas social studies curricula were more likely than science materials to mention collective responses, such as new laws and the Kyoto Protocol, only five total curricula mention a cap-and-trade system. Rather, the materials are much more likely to mention individual-level responses, such as riding a bike instead of driving a car (see Table 5). Moreover, these findings indicate that few materials published between 2007 and 2012 to teach about GCC to U.S. high school students thoroughly portray its causes, consequences, or potential responses. As we consider how to prepare young people for our collective future, it is vital for educators, scholars, curriculum writers, and policymakers to understand exactly how GCC curricula can fall short in communicating important information about this vital global challenge. 


\section{2 | Practical implications}

The findings of this research have several important practical implications. Many factors contribute to students' and educators perceptions of GCC, but the content of curricular materials can be vital because they can substantially affect what students learn in classrooms (e.g., Schmidt et al., 2002). Given the limited and often problematic portrayals of GCC in the materials we analyzed, recent U.S. high school graduates who used these materials may be poorly informed about GCC and unprepared to respond to it. If citizens in a democratic society are to engage in nuanced deliberation about GCC, they must have at least a basic understanding of the causes, likely consequences, and range of possible responses.

First, moving forward, those who write curricula and/or teach about GCC should ensure that what they communicate about the causes of the problem reflects the broad scientific consensus described in the IPCC reports (2007, 2014), numerous supporting studies (e.g., Anderegg et al., 2010, U.S. Global Change Research Program, 2017), and the Next Generation Science Standards (2013). Six of the textbooks analyzed in this study present the causes of climate change as an open question, and two supplemental materials outright reject the idea of anthropogenic climate change (see Table 3) - contrary to IPCC reports issued before they were published. Meanwhile, some adherent materials exaggerate the likely consequences of GCC (see Table 4). To best support students' understanding of this issue, authors and organizations that develop curricula on climate change should ensure that their publications reflect the scientific consensus about GCC's substantial human causes. When teaching this topic, educators should carefully assess their written materials before using them in the classroom — and may find it useful to include multiple curricula. Nonetheless, if educators think that disciplinary norms 
require them to address the controversies around the causes, as social studies teachers might (e.g., Ho \& Seow, 2015; NCSS, 2013), they may find it valuable to help students explore the reasons that mass media and others in the public sphere portray the issue as more controversial than do scientific reports.

Second, this study's findings highlight the variety of ways that GCC's consequences are and can be positioned (see Table 3 and Appendix) — and thereby enable us to identify ways to make these issues more relevant for youth. Indeed, many materials in this study situated GCC's effects as distant temporally (from the present) and geographically (from the United States), despite the fact that climatic changes are already occurring and having impacts in the United States and across the planet (IPCC, 2014; USGCRP, 2017). Such environmental disruptions do and will contribute to adverse effects on human livelihood, including freshwater scarcity (IPCC, 2014, p. 14), flooding of coastal population centers (p. 17), price instability and access to food (p. 18), increased risks from heat and water-borne illnesses (p. 19), and migration and (re)settlement patterns (p. 20), especially for those living in poverty (p. 20).

Indeed, studying GCC in school offers opportunities for exploring a range of social issues that students may find personally meaningful — and that could have a direct impact on their lives, and teachers can help students understand the potential proximity of GCC's consequences (e.g., Levy et al., in press). Thus, as with the causes of GCC, educators should carefully assess the curricula that they plan to use, consider using additional materials, and leverage some of these social issues as hooks to explore topics unaddressed in their texts, such as adaptation and inequality. Meanwhile, teachers could assign their students to compare different curricular materials as we have, asking them to consider why GCC's causes and consequences are portrayed in such different ways. 
In addition, because the materials analyzed in this study focus nearly exclusively on mitigation strategies, they imply that mitigating GCC's causes can prevent or quickly reverse the effects of climate change. Unfortunately, such content does not prepare youth to think about how our communities could adapt to and prepare for the ongoing and anticipated impacts. For example, how will the shift in agricultural yields and cropping patterns resulting from warmer temperatures affect how we procure food? What types of policies should we have in place to help climate refugees (those displaced from their communities by extreme weather events) within and across nation-states? How should we prepare our communities to deal with new climate realities like prolonged heat waves, intensified storm activity, and rising sea levels? Who will be most affected by these impacts? Thus, a third practical implication of this study is that educators and curricular materials can and should play a stronger role in helping young people consider such policy dilemmas to prepare for the choices ahead.

Moreover, as Gough (2002) and Hodson (2003) have argued, science education may better serve students and society as a whole if teachers oriented their courses to prepare students to collectively address our environmental challenges. The bulk of the curricula in the present study, especially the nonsocial studies-focused materials, communicate only about actions that individuals can pursue independently, with limited attention to actions that would affect institutions or policies (see Table 5). To prepare students for the numerous options for addressing climate change (including business opportunities), curriculum writers should expand the range of civic actions they suggest individuals and groups could undertake to respond to the problem, and until this happens, science educators could seek either additional curricular resources or collaborations with other educators. Teachers of science and social studies may find it mutually 
beneficial to meet regularly to plan their instruction related to GCC to ensure that students have opportunities to thoroughly explore the causes, consequences, and potential responses.

Indeed, social, economic, and environmental concerns are inextricably intertwined (WCED, 1987) in sustainability-related issues, and students need a more complete picture of GCC than either science or social studies classrooms provide on their own (Feinstein \& Kirchgasler, 2015). Whereas in science class students may learn about the physical basis of climate change and its impacts, social studies educators may be better equipped to help students consider equally important historical, ethical, political, and economic elements. Curriculum developers could help to facilitate such collaborations between teachers from different subject areas by designing materials that integrate standards-based GCC content related to typical high school courses, such as government and earth science. Thus, besides assessing, revising, and supplementing existing curricula, educators and curriculum developers could work to develop and enact new curricula in ways that break down traditional subject area boundaries.

\section{3 | Implications for future research}

Given this study's findings about how curricula published between 2007 and 2012 portray the causes, consequences, and potential responses to GCC, educational researchers should continue to examine and monitor how curricular materials portray the issue. It is possible that climate change curricula published since the 2014 IPCC report communicate a significantly different message than those analyzed in this study, especially as the public and curriculum developers take note of climate-related phenomena, such as warmer winters and disasters related to extreme weather. Certain extreme events, such as Superstorm Sandy in 2012 or Hurricane Irma in 2017, have spurred policymakers across the country to begin developing adaptation strategies (Paulson, 
2017; Peltz, 2013) — but such events may or may not have affected curricula. Thus, it is very important for those concerned about GCC to continue exploring how curricula portray this vital issue so that today's youth will be well prepared to address the challenges they will face.

Meanwhile, researchers should consider how portrayals of the causes, consequences, and potential responses to climate change also reflect or reinforce cultural biases and assumptions about who contributes to and addresses these problems across the globe (e.g., Ideland \& Malmberg, 2014). Texts (including multimedia) may directly or indirectly address many questions, including the following: How does and how will GCC affect societies in different parts of the world? Which communities are contributing most to GCC's causes, and how could or should this affect adaptation and mitigation strategies? What response options should be emphasized - technological or sociopolitical, personal, or societal? In exploring curricula about GCC, researchers may find it valuable not only to empirically analyze text — but also to consider and question the philosophical and cultural underpinnings of these portrayals.

And finally, although the findings in this paper highlight shortcomings of many curricular materials on GCC, this does not mean that educators' instruction adheres to this content. Therefore, it is important to continue to explore instruction and educators' conceptions related to GCC. Whereas curricula adopted by schools and districts can influence classroom content (Schmidt et al., 2002; Sun et al., 2009), many science teachers believe they should present both sides of the debate concerning the causes of climate change (Wise, 2010), suggesting that the public controversy around the issue may influence their instruction. Furthermore, teachers often struggle with whether and how they should disclose their views on controversial environmental topics (Cotton, 2006). More research on how teachers conceptualize, create, and use GCC content in their classrooms would offer a richer understanding of how we are preparing young 
people to respond to the problem. For example, case studies that highlight the practices of singlesubject teachers or collaborations involving educators with different content specializations could provide models that others could emulate or improve upon. Finally, researchers could explore the ways and extent to which teacher education programs are preparing educators to design and enact instruction related GCC. Ultimately, such research could enhance our understanding of how we can strengthen the next generation's understanding of GCC and how to respond to it.

\section{7 | LIMITATIONS AND CONCLUSION}

Global climate change is one of the most serious issues of our time, and it is likely to affect ecosystems, economies, and social systems for generations (IPCC, 2014). Thus, it is vital that educators and educational researchers pay close attention to how young people are — or are notlearning about its various dimensions, including how to respond to it. In addition to the practical and research implications discussed above, this study's findings raise a number of theoretical and philosophical questions. For example, what do we want youth to be able to do about GCC, and how does this challenge or support our notions of what it means to be a citizen in our democracy? Furthermore, what is the right age at which to begin grappling with these challenging issues?

At a more basic level, however, our findings suggest that many U.S. high school curricula have been inadequate resources for preparing youth to understand and respond to climate change. This study, of course, had certain limitations based on the sample and our own perspectives. We analyzed content from five science textbooks, four social studies textbooks, and eight sets of supplemental materials intended for use by U.S. high school students, all published between 
2007 and 2012 — so there are numerous curricular resources not included in our sample.

Furthermore, our analytical framework focused on issues pertinent in a U.S. context, such as acceptance of or dissent from the scientific consensus regarding the human causes of GCC.

Nonetheless, what we found in our close analysis of 17 sets of widely used materials indicates that many of the most popular curricula published during this period did not integrate updated scientific findings about GCC, and none included thorough explorations of potential human responses to the problem. Such inadequacies may have limited (and, if still in use, may still limit) students' learning about GCC. Given the potential impacts of GCC in the decades to come, we believe that continually monitoring and strengthening curricular resources on this issue should be a high priority. 


\section{REFERENCES}

American Association for the Advancement of Science. (1993). Benchmarks, Project 2061.

Retrieved from https:// www.project2061.org/publications/bsl/

online/index.php?home=true

Anderegg, W., Prall, J., Harold, J., \& Schneider, S. (2010). Expert credibility in climate change. Proceedings of the National Academy of Sciences, 107(27), 12107-12109. https://doi.org/10.1073/pnas.1003187107

Andersson, B., \& Wallin, A. (2000). Students' understanding of the greenhouse effect, the social consequences of reducing $\mathrm{CO}_{2}$ emissions and the problem of ozone layer depletion. Journal of Research in Science Teaching, 37(10), 1096-1111.

Araujo, D. C., Jordan, S. D., \& Lindsay, R. A. (2008). Textbook accuracy report: An analysis of James Q. Wilson and John J. Jilulio, Jr.’s American Government: Institutions and Policies. Amherst, MA: The Center for Inquiry. Retrieved from https:// www.centerforinquiry.net/uploads/attachments/CFI_Textbook_Critique_Compare.pdf

Ball, D. B., \& Cohen, D. K. (1996). Reform by the book: What is —or what might be - the role of curriculum materials in teacher learning and instructional reform. Educational Researcher, 25(9), 6-8, 14.

Belanger, E., \& Meguid, B. M. (2008). Issue salience, ownership, and issue-based vote choice. Electoral Studies, 27, 477-491.

Bencze, L., \& Carter, L. (2011). Globalizing students acting for the common good. Journal of Research in Science Teaching, 48(6), 648-669. 
Bengtsson, S. L., \& Ostman, L. O. (2013). Globalisation and education for sustainable development: Emancipation from context and meaning. Environmental Education Research, 19(4), 477-498.

Bisland, B., \& Ahmad, I. (2008). Climate change draws world attention: The Nobel Peace Prize goes to Gore and IPCC. Social

Education, 72(2), 69-74.

Blystone, R. V. (1989). Biology learning based on illustrations. In National Research Council (Ed.), Fulfilling the promise: Biology education in the nation's schools (pp. 27). Washington, DC: National Academy Press.

Boykoff, M. T. (2013). Public enemy no. 1? Understanding media representations of outlier views on climate change. American Behavioral Scientist, 57(5), 796-817.

Boyes, E., \& Stanisstreet, M. (1998). High school students' perceptions of how major global environmental effects might cause skin cancer. Journal of Environmental Education, 29(2), 31-36.

Brace, C., \& Geoghegan, H. (2011). Human geographies of climate change: Landscape, temporality, and lay knowledges. Progress in Human Geography, 35(3), 284-302.

Brown, L. R. (2011). World on the edge. New York, NY: Norton.

Butler, D. M., \& Nickerson, D. W. (2011). Can learning constituency opinion affect how legislators vote? Results from a field experiment. Quarterly Journal of Political Science, $6(1), 55-83$.

Caranto, B. F., \& Pitpitunge, A. D. (2015). Students' knowledge on climate change: Implications on interdisciplinary learning. In E. Gnanamalar Sarojini Daniel (Ed.), Biology education and research in a changing planet (pp. 21-30). Singapore: Springer. 
Chambers, J., \& Rowell, P. (2005). Managing uncertainty in climate change education: From governments to schools. In D. Fisher, D. Zandvliet, I. Gaynor, \& R. Koul (Eds.), Proceedings of the fourth international conference on science, mathematics, and technology education (pp. 81-89). Perth, Australia: Key Centre for School Science and Mathematics.

Chandler, T., \& Marri, A. R. (2012). Civic engagement about climate change: A case study of three educators and their practice. Journal of Social Studies Research, 36(1), 47-74.

Chang, C., \& Pascu, L. (2015). "The hold in the sky causes global warming”: A case study of secondary school students' climate change alternative conceptions. Review of International Geographical Education Online (RIGEO), 5(3), 316-331.

Chingos, M. M., \& Whitehurst, G. J. (2012). Choosing blindly: Instructional materials, teacher effectiveness, and the common core. Washington, DC: Brown Center on Education Policy at Brookings.

Choi, S., Niyogi, D., Shepardson, D., \& Charusombat, U. (2010). Do earth and environmental science textbooks promote middle and high school student conceptual development about climate change? Textbooks' consideration of students' misconceptions. Bulletin of the American Meteorological Society, 91(7), 889-898.

Corbin, J., \& Strauss, A. (2008). Basics of qualitative research (3rd ed.). Thousand Oaks, CA: Sage.

Cotton, D. (2006). Teaching controversial environmental issues: Neutrality and balance in the reality of the classroom. Educational Research, 48(2), 223-241. 
Dalelo, A.A. (2011). Global climate change in geography curricula for Ethiopian secondary and preparatory schools. International Research in Geographical \& Environmental Education, 20(3), 227-246. https://doi.org/10.1080/ 10382046.2011.588505

Dempsey, C., Bodzin, A., Peffer, T., Anastasio, D., Sahagian, D., Cirucci, L., \& Bressler, D.(2013). Environmental literacy and inquiry: The climate change curriculum. Paper presented at the annual international meeting of the Association for the Education of Teachers in Science, Charleston, South Carolina.

Derek Hodson (2003). Time for action: Science education for an alternative future, International Journal of Science Education, 25(6) 645-670, https://doi.org/10.1080/09500690305021

De Young, R. (2000). Expanding and evaluating motives for environmentally responsible behavior. Journal of Social Issues, 56(3), 509-526.

Donovan, S., \& Bransford, J. D. (2005). How Students Learn: History, Mathematics, and Science in the Classroom: National Academies Press.

Doyle, T., \& Kellow, A. (1995). Environmental politics and policymaking in Australia. South Melbourne, Australia: Macmillan Education Australia.

Education Market Research. (2010). Complete K-12 report: Market facts \& segment analyses. Rockway Park, NY: Education Market Research.

Feinstein, N. W., \& Kirchgasler, K. L. (2015). Sustainability in science education? How the Next Generation Science Standards approach sustainability, and why it matters. Science Education, 99(1), 121-144

Feldman, L., Maibach, E. W., Roser-Renouf, C., \& Leiserowitz, A. (2012). Climate on cable: The nature and impact of global warming coverage on Fox News, CNN, and MSNBC. The International Journal of Press/Politics, 17(1), 3-31. 
Feldman, L., Nisbet, M. C., Leiserowitz, A., \& Maibach, E. W. (2010). The climate generation? Survey analysis of the perceptions and beliefs of young Americans. Joint Report of American University's School of Communication, The Yale Project on Climate Change, and George Mason University's Center for Climate Change Communication. Available online at https://environment.yale.edu/climate-communicationOFF/files/YouthJan2010.pdf

Ferreira, A. H., Curtis, S., Chia, R., Poe, E., Thompson, R., \& Yang, B. (2012). A multinational course on global climate change. Bulletin of the American Meteorological Society, 93, $1539-1546$.

Fishbein, M., \& Ajzen, I. (2010). Predicting and changing behavior: The reasoned action approach. New York, NY: Psychology Press. Freeman, D. J., \& Porter, A. C. (1989). Do textbooks dictate the content of mathematics instruction in elementary schools? American Educational Research Journal, 26(3), 403-421.

Gallup. (2017). Global warming concern at three-decade high in US. Retrieved from https://www.gallup.com/poll/206030/global- warming-concern-three-decadehigh.aspx?g_source=CATEGORY_CLIMATE_CHANGE\&g_medium=topic\&g_campai gn $=$ tiles

Gannet Hallar, A., McCubbin, I. B., \& Wright, J. M. (2011). A Place-Based Curriculum for Understanding Climate Change at Storm Peak Laboratory, Colorado. Bull. Amer. Meteor. Soc., 92, 909-918. https://doi.org/10.1175/2011BAMS3026.1

Gardner, T. (2011, June 28). US climate skeptic Soon funded by oil, coal firms. Reuters. Retrieved from https:// af.reuters.com/article/energyOilNews/ idAFN1E75Q1ZO20110628?pageNumber=1\&virtualBrandChannel=0 
Gaudelli, W., \& Heilman, E. (2009). Reconceptualizing geography as democratic global citizenship education. Teachers College Record, 111(11), 2647-2677.

Gough, A. (2002). Mutualism: A different agenda for environmental education and science education. International Journal of Science Education, 24(11), 1201-1215.

Government of Canada. (2002). A framework for environmental learning and sustainability in Canada. National Library of Canada.

Gowda, M., Fox, J., \& Magelky, R. (1997). Students' understanding of climate change: Insights for scientists and educators. Bulletin of the American Meteorological Society, 78(10), 2232-2240.

Grossman, P., \& Thompson, C. (2008). Learning from curriculum materials: Scaffolds for new teachers? Teaching and Teacher Education, 24, 2014-2026.

Hamilton, L. C. (2011). Education, politics and opinions about climate change evidence for interaction effects. Climatic Change, 104(2), 231-242.

Hauser, N. (2009). Ecological democracy: An environmental approach to citizenship education. Theory and Research in Social Education, 37(2), 211-214.

Herman, B. C. (2014). The influence of global warming science views and sociocultural factors on willingness to mitigate global warming. Science Education, 99(1), 1-38.

Herman, B. C., Feldman, A., \& Vernaza-Hernandez, V. (2017). Florida and Puerto Rico secondary science teacher's knowledge and teaching of climate change science. International Journal of Science and Math Education, 15(3), 451-471.

Hess, D. (2009). Controversy in the classroom: The democratic power of discussion. New York, NY: Routledge. 
Hess, D., \& Stoddard, J. (2007). 9/11 and terrorism: "The ultimate teachable moment" in textbooks and supplemental curricula. Social Education, 71, 231-236.

Hestness, E., McGinnis, J. R., Breslyn, W., McDonald, R. C., \& Mouza, C. (2017). Examining science educators' perspectives on learning progressions in a climate change education professional development program. Journal of Science Teacher Education, 28(3), 250274.

Ho, L.-C., \& Seow, T. (2015). Teaching controversial issues in geography: Climate change education in Singaporean schools. Theory \& Research in Social Education, 43(3), 314344.

Hodson, D. (2003). Time for action: Science education for an alternative future. International Journal of Science Education, 25(6), 645-670.

Ideland, M., \& Malmberg, C. (2014). "Our common world" belongs to "Us": Constructions of otherness in education for sustainable development. Critical Studies in Education, 55(3), 369-386.

International Panel on Climate Change. (2001). Climate change 2001: Synthesis report. Retrieved from https:// gridarendal-website.s3.amazonaws.com/production/ documents/:s_document/286/original/q1 to9.pdf?1488203631

International Panel on Climate Change. (2007). Climate change 2007: Synthesis report. Retrieved from https://www.ipcc. ch/publications_and_data/ar4/syr/en/contents.html International Panel on Climate Change. (2014). Summary for policymakers. In C. B. Field, V. R. Barros, D. J. Dokken, K. J. Mach, M. D. Mastrandrea, T. E. Bilir, ... L. L. White (Eds.), Climate change 2014: Impacts, adaptation, and vulnerability. Part A: Global and sectoral aspects. Contribution of Working Group II to the Fifth Assessment Report of the 
Intergovernmental Panel on Climate Change (pp. 1-32). Cambridge, England: Cambridge University Press.

Jacobson, M. J., Markauskaite, L., Portolese, A., Kapur, M., Lai, P. K., \& Roberts, G. (2017). Designs for learning about climate change as a complex system. Learning and Instruction, 52, 1-14.

Jickling, B., \& Wals, A. E. J. (2008). Globalization and environmental education looking beyond sustainable development. Journal of Curriculum Studies, 40, 1-21

Johnson, R. M., Henderson, S., Gardiner, L., et al. (2008). Lessons learned through our climate change professional development program for middle and high school teachers, Physical Geography, 29(6), 500-511. https://doi.org/10.2747/0272-3646.29.6.500

King, C. H. (2010). An analysis of misconceptions in science textbooks: Earth science in England and Wales. International Journal of Science Education, 32(5), 565-601.

Klosterman, M., \& Sadler, T. (2010). Multi-level assessment of scientific content knowledge gains associated with socioscientific issues-based instruction. International Journal of Science Education, 32(8), 1017-1043.

Kolmuss, A., \& Agyeman, J. (2002). Mind the gap: Why do people act environmentally and what are the barriers to pro- environmental behavior? Environmental Education Research, 8(3), 239-260.

Kumler, L. M. (2011). Students of action? A comparative investigation of secondary science and social studies students' action repertoires in a land use context. The Journal of Environmental Education, 42(1), 14-29.

Ladson-Billings, G. (2016). And then there is this thing called the curriculum: Organization, imagination, and the mind. Educational Researcher, 45(2), 100-104. 
Launder, B., \& Thompson, J. (2010). Geoengineering climate change: Environmental necessity or Pandora's box? Cambridge, England: Cambridge University Press.

Lambert, J. L., Lindgren, J., \& Bleicher, R. (2012). Assessing elementary science methods students' understanding about global climate change. International Journal of Science Education, 34(8), 1167-1187.

Leiserowitz, A., Maibach, E., Roser-Renouf, C., Feinberg, G., \& Howe, P. (2012). Climate change in the American mind: Americans' global warming beliefs and attitudes in September, 2012. Yale Project on Climate Change Communication. New Haven, CT: Yale University and George Mason University. Retrieved from https://environment.yale.edu/ climate/files/Climate-Beliefs-September-2012.pdf

Leiserowitz, A., Maibach, E., Roser-Renouf, C., Feinberg, G., \& Howe, P. (2013). Climate change in the American mind: Americans' global warming beliefs and attitudes in April, 2013. Yale Project on Climate Change Communication. New Haven, CT: Yale University and George Mason University. Retrieved from https://environment.yale.edu/ climate/files/Climate-Beliefs-April-2013.pdf

Leiserowitz, A., Maibach, E., Roser-Renouf, C., Feinberg, G., \& Rosenthal, S. (2015). Climate change in the American mind: March, 2015. Yale Project on Climate Change Communication. New Haven, CT: Yale University and George Mason University. Retrieved from https://environment.yale.edu/climate-communication/files/GlobalWarming-CCAM-March-2015.pdf

Leiserowitz, A., Maibach, E., Roser-Renouf, C., \& Smith, N. (2011). Global warming's six Americas, May 2011. Yale Project on Climate Change Communication. New Haven, CT: 
Yale University and George Mason University. Retrieved from https://environment.yale.edu/climate/publications/

Levy, B. L. M., Harris, C. B., Collet-Gildard, L., Long, G., Sperling, E., \& Dacus, L. C. (in press). Preparing youth for environmental civic engagement: Inquiry-based social studies education for sustainability and ecojustice. In M. Crocco, J. Passe, \& B. Vosburg-Bluem (Eds.), National Council for the Social Studies bulletin. Washington, DC: National Council for the Social Studies.

Lombardi, D., \& Sinatra, G. (2012). Emotions about teaching about human-induced climate change. International Journal Of Science Education, 35(1), 167-191.

Lubell, M. (2002). Environmental activism as collective action. Environment \& Behavior, 34(4), $431-454$.

Lubell, M., Zahran, S., \& Vedlitz, A. (2007). Collective action and citizen responses to global warming. Political Behavior, 29, 391- 413.

Macnaghton, P., \& Bronislaw, S. (2017). Geoengineering and the debate about governance. In D. Richardson, N. Castree, M. F. Goodchild, A. Kobayashi, W. Liu, \& R. A. Marston (Eds.), International Encyclopedia of Geography (pp. 2617-2623). Hoboken, NJ: Wiley.

Macnaghten, P., \& Szerszynski, B. (2017). Geoengineering/Climate Intervention. The International Encyclopedia of Geography, 1-7.

Maibach, E., Roser-Renouf, C., \& Leiserowitz, A. (2009). Global warming's six Americas 2009: An audience segmentation analysis. Yale Project on Climate Change Communication. New Haven, CT: Yale University and George Mason University. Retrieved from https://environment.yale.edu/climate/publications/ 
Mannion, G., Biesta, G., Priestley, \& Ross, H. (2011). The global dimension in education and education for global citizenship: Genealogy and critique, Globalisation, Societies and Education, 9(3-4), 443-456, https://doi.org/10.1080/14767724.2011.605327

Matkins, J. J., \& Bell, R. L. (2007). Awakening the scientist inside: Global climate change and the nature of science in an elementary science methods course. Journal of Science Teacher Education, 18(2), 137-163.

McKeown-Ice, R., \& Dendinger, R. (2000). Socio-political-cultural foundations of environmental education. The Journal of Envi- ronmental Education, 31(4), 37-45.

McGinnis, J. R., McDonald, C., Breslyn, W., \& Hestness, E. (2017). Supporting the inclusion of climate change in U.S. science education curricula by use of learning progressions. In D. Shepardson, A. Roychoudury, \& A. Hirsch (Eds.), Teaching and learning about climate change: A framework for educators (pp. 135-151). New York, NY: Routledge.

McMakin, A. (2002). Motivating residents to conserve energy without financial incentives. Environment \& Behavior, 34, 848- 863.

McNeil, K., \& Vaughn, M. (2012). Urban high school students' critical science agency: Conceptual understandings and environ- mental actions around climate change. Research in Science Education, 42(2), 373-399.

Milfont, T. L., Wilson, M. S., \& Sibley, C. G. (2017). The public's belief in climate change and its human cause are increasing over time. PLoS One, 12(3), e0174246.

National Aeronautics and Space Administration (2017). Global climate change: Vital signs of the planet. Retrieved from https://climate.nasa.gov/

National Center for Educational Statistics. (2014). Learning contexts: Classroom practices. Retrieved from https://www. nationsreportcard.gov/hgc_2014/\#history/contexts 
National Council for the Social Studies. (2007). Academic freedom and the social studies teacher: A position statement of the National Council for the Social Studies. Retrieved from https://www.socialstudies.org/positions/academicfreedom

National Council for the Social Studies (NCSS). (2013). The College, Career, and Civic Life (C3) Framework for Social Studies State Standards: Guidance for Enhancing the Rigor of K-12 Civics, Economics, Geography, and History. Silver Spring, MD: NCSS. Retrieved from https://www.socialstudies.org/system/files/c3/C3-Framework-for-SocialStudies.pdf. Accessed June 9, 2016.

National Research Council (n.d.). Climate change evidence, impacts, and choices: Answers to common questions about the science of climate change. Retrieved from https://nassites.org/americasclimatechoices/more-resources-on-climate-change/climate- changelines-of-evidence-booklet/

National Research Council. (1996). National Science Education Standards. Washington, DC: The National Academies Press. Retrieved from https://doi.org/10.17226/4962

National Science Teachers Association (NSTA). (2016). NSTA Position Statement: Teaching Science in the Context of Societal and Personal Issues.

Nejat, P., Jomehzadeh, F., Taheri, M. M., Gohari, M., \& Majid, M. Z. (2015). A global review of energy consumption, $\mathrm{CO}_{2}$ emissions, and policy in the residential sector (with an overview of the top ten $\mathrm{CO}_{2}$ emitting countries). Renewable and Sustain- able Energy Reviews, 43, 843-862.

Newport, F. (2010). Americans' global warming concerns continue to drop. Retrieved from https://www.gallup.com/ poll/126560/Americans-Global-Warming-Concerns-ContinueDrop.aspx 
Newstadt, M. R. (2015). The complexities, persistence, and relationships among middle school students' climate change stances and knowledge (Unpublished doctoral dissertation). University of Michigan, Ann Arbor.

NGSS Lead States. (2013). Next Generation Science Standards. Retrieved from https://www.nextgenscience.org/next-generation -science-standards

Nussbaum, E., Owens, M. C., Sinatra, G., Rehmat, A., Cordova, J., Ahmad, S., ... Dascalu, S. (2015). Losing the lake: Simulations to promote gains in student knowledge and interest about climate change. International Journal of Environmental \& Science Education, 10(6), 789-811.

Nussbaum, E. M., Cordova, J. R., \& Rehmat, A. P. (2017). Refutation texts for effective climate change education. Journal of Geoscience Education, 65, 23-34.

Parchmann, I., Grasel, C., Baer, A., Nentwig, P., Demuth, R., \& Ralle, B. (2006). “Chemie im Kontext": A symbiotic implementation of a context-based teaching and learning approach. International Journal of Science Education, 28(9), 1041-1062.

Patton, M. (2002). Qualitative evaluation methods (3rd ed.). Beverly Hills, CA: Sage. Paulson, A. (2017). Can resilience planning be disentangled from climate politics? The Christian Science Monitor. Retrieved from https://www.csmonitor.com/Environment/ 2017/0915/Can-resilience-planning-be-disentangled-from-climate-politics

Peltz, J. (2013, June 11). Climate change in NYC: Mayor Bloomberg to discuss prepping city for warming world. Huffington Post.

Pew Research Center. (2011, December 1). Modest rise in number saying there is "solid evidence" of global warming: More moderate Republicans see evidence of warming. Retrieved from https://people-press.org 
Pew Research Center. (2015, June 16). Ideological divide over global warming as wide as ever. Retrieved from https://www. pewresearch.org/fact-tank/2015/06/16/ideological-divideover-global-warming-as-wide-as-ever/?_ga=1.117338566. 1756761979.1446488693

Pew Research Center. (2016, October 4). The politics of climate. Retrieved from https://assets.pewresearch.org/wp-content/ uploads/sites/14/2016/10/14080900/PS_2016.10.04_Politics-of-Climate_FINAL.pdf

Porter, D., Weaver, A. J., \& Raptis, H. (2012). Assessing students' learning about fundamental concepts of climate change under two different conditions. Environmental Education Research, 18(5), 665-686.

Preston, C. J. (2011). Re-thinking the unthinkable: Environmental ethics and the presumptive argument against geoengineering. Environmental Values, 20(4), 457-479.

Pruneau, D., Gravel, H., Courque, W., \& Langis, J. (2003). Experimentation with a socioconstructivist process for climate change education. Environmental Education Research, 9(4), 429-446.

Reidsma, P., Ewert, F., Lansink, A. O., \& Leemans, R. (2010). Adaptation to climate change and climate variability in European agriculture: The importance of farm level responses. European Journal of Agronomy, 32(1), 91-102.

Román, D., \& Busch, K. C. (2016). Textbooks of doubt: Using systemic functional analysis to explore the framing of climate change in middle-school science textbooks. Environmental Education Research, 22(8), 1158-1180.

Roser-Renouf, C., Maibach, E., Leiserowitz, A., Feinberg, G., Rosenthal, S., \& Kreslake, J. (2014). Global warming's six Americas, October, 2014: Perception of the health consequences of global warming and update on key beliefs. Yale Project on Climate 
Change Communication. New Haven, CT: Yale University and George Mason University. Retrieved from https://environment.yale.edu/climate/publications/

Roser-Renouf, C., Maibach, E. W., Leiserowitz, A., \& Xianoquan, Z. (2014). The genesis of climate change activism: From key beliefs to political action. Climatic Change, 125, $163-178$.

Roychoudhury, A., Shepardson, D. P., Hirsch, A., Niyogi, D., Mehta, J., \& Top, S. (2017). The need to introduce system thinking in teaching climate change. Science Educator, 25(2), $73-81$.

Rudolph, J. L. (2014). Dewey's "science as method" a century later: Reviving science education as civic ends. American Educational Research Journal, 6(51), 1056-1083.

Rye, J., Strong, D., \& Rubba, P. (2001). Global warming and ozone layer depletion: STS issues for social studies classrooms. Social Education, 65(2), 90-95.

Sadler, T. D., Romine, W. L., Stuart, P. E., \& Merle-Johnson, D. (2013). Game-based curricula in biology classes: Differential effects among varying academic levels. Journal of Research in Science Teaching, 50(4), 479-499.

Shabecoff, P. (2003). A fierce green fire: The American environmental movement. Washington, DC: Island.

Schmidt, W., Houang, R., \& Cogan, L. (2002). A coherent curriculum: The case of mathematics. American Educator.

Sinatra, G. M., Kardash, C. M., Taasoobshirazi, G., \& Lombardi, D. (2012). Promoting attitude change and expressed willingness to take action toward climate change in college students. Instructional Science: An International Journal of the Learning Sciences, 40(1), $1-17$. 
Sun, Y., Kulm, G., \& Capraro, M. M. (2009). Middle grade teachers' use of textbooks and their classroom instruction. Journal of Mathematics Education, 2(2), 20-37.

Svoboda, T., Keller, K., Goes, M., \& Tuana, N. (2011). Sulfate aerosolo geoengineering: The question of justice. Public Affairs Quarterly, 25(3), 157-179.

United Nations Framework Convention on Climate Change (UNFCCC). (2004). The First Ten Years. Halesworth, UK: Climate Change Secretariat (UNFCCC). Retrieved from https://unfccc.int/resource/docs/publications/first_ten_years_en.pdf

United Nations Educational, Scientific and Cultural Organization (UNESCO). (2017). Global Education Monitoring Report - Accountability in education: Meeting our commitments. Retrieved from https://unesdoc.unesco.org/ images/0025/002593/259338e.pdf

U.S. Department of Defense. (2014). Climate change adaptation roadmap. Washington, DC: Office of the Deputy Undersecretary of Defense. Retrieved from https://www.acq.osd.mil/eie/Downloads/CCARprint_wForward_e.pdf

U.S. Department of Defense. (2015). National security implications of climate-related risks and a changing climate. Washington, DC: U.S. Department of Defense. Retrieved from https://archive.defense.gov/pubs/150724-congressional- report-on-national-implicationsof-climate-change.pdf? source= govdelivery

U.S. Global Change Research Program. (2017). Climate science special report: Fourth national climate assessment, volume 1. D. J. Wuebbles, D. W. Fahey, K. A. Hibbard, D. J. Dokken, B. C. Stewart, \& T. K. Maycock (Eds.). Washington, DC: U.S. Global Change Research Program. https://doi.org/10.7930/J0J964J6

Wade, R. C. (1993). Content analysis of social studies textbooks: A review of ten years of research. Theory \& Research in Social Education, 21(3), 232-256. 
Wals, A. E. J., Weakland, J. P., \& Corcoran, P. B. (2017). Introduction. In P. B. Corcoran, J. P. Weakland, \& A. E. J. Wals (Eds.), Envisioning futures for environmental and sustainability education (pp. 19-29). Wageningen, The Netherlands: Wageningen Academic Publishers.

Wise, S. (2010). Climate change in the classroom: Patterns, motivations, and barriers to instruction among Colorado science teachers. Journal of Geoscience Education, 58(5), 297-309.

World Commission on Environment and Development. (1987). Report of the World Commission on environment and development: Our common future. 43, Retrieved from https://www.un-documents.net/our-common-future.pdf

Youniss, J., Bales, S., Christmas-Best, V., Diversi, M., McLaughlin, M., \& Silbereisen, R. (2002). Youth civic engagement in the twenty-first century. Journal of Research on Adolescence, 12, 121-148.

Zinth, K. (2005). State notes: Textbook adoption. Retrieved from https://www.ecs.org/ clearinghouse/57/75/5775.pdf 


\section{APPENDIX | Key Codes and Sub-Codes}

\begin{tabular}{|c|c|c|}
\hline \multicolumn{3}{|c|}{ Climatic Changes - changes in earth systems due to accelerated greenhouse effect } \\
\hline Sub-Code & Definition & Example \\
\hline temperature & $\begin{array}{l}\text { increase in atmosphere and/or sea } \\
\text { temperature }\end{array}$ & $\begin{array}{l}\text { Figure } 17 \text { shows that during the twentieth century, Earth's } \\
\text { average surface temperatures increased about } 1.0 \\
\text { C. Scientists predict that by the year } 2100 \text {, temperatures } \\
\text { could increase by more than another 5C. (PH-Earth Sci; p. } \\
602 \text { ) }\end{array}$ \\
\hline precipitation & $\begin{array}{l}\text { change in precipitation, long term } \\
\text { droughts, flooding due to precip }\end{array}$ & $\begin{array}{l}\text { Some of the world's most water-stressed regions, (e.g., } \\
\text { northeastern Brazil, southern Africa, the southwestern } \\
\text { United States and northern Mexico) are likely to see a } 10 \text { to } \\
30 \text { percent decline in water availability by the end of the } \\
\text { century (AIT in Classroom, p. 19) }\end{array}$ \\
\hline sea level & rise in sea level & $\begin{array}{l}\text { Although not all people agree that global warming is } \\
\text { occurring, scientists who study it warn that the increase in } \\
\text { temperature will cause glaciers and ice caps to melt, raising } \\
\text { the level of the world's oceans. (Gl-World Geo; p. 110) }\end{array}$ \\
\hline $\begin{array}{l}\text { extreme } \\
\text { events }\end{array}$ & $\begin{array}{l}\text { increase in expected extreme } \\
\text { storms \& heat waves }\end{array}$ & $\begin{array}{l}\text { Warmer oceans could also lead to stronger and more } \\
\text { frequent storms, including hurricanes. (PH-Earth Sci; p. } \\
603 \text { ) }\end{array}$ \\
\hline \multicolumn{3}{|c|}{$\begin{array}{l}\text { Impacts \& Vulnerabilities - aspects of human and earth systems that will be impacted by accelerated } \\
\text { greenhouse effect }\end{array}$} \\
\hline Sub-Code & Definition & Example \\
\hline food security & changes to patterns of food yield & $\begin{array}{l}\text { If this trend continues, deserts will expand and crops will } \\
\text { fail. (ML-Mod World Hist; p. 679) }\end{array}$ \\
\hline $\begin{array}{l}\text { water } \\
\text { resources }\end{array}$ & $\begin{array}{l}\text { quality/amount of fresh water } \\
\text { available for human/ecosystem } \\
\text { use }\end{array}$ & $\begin{array}{l}\text { Rising sea levels cause salt water to move farther inland, } \\
\text { often contaminating drinking water resources (Facing the } \\
\text { Future, p. 33) }\end{array}$ \\
\hline $\begin{array}{l}\text { ecosystem- } \\
\text { Physical }\end{array}$ & $\begin{array}{l}\text { change in defining ecosystem } \\
\text { attributes }\end{array}$ & $\begin{array}{l}\text { Oceans have become more acidic due to increased } \mathrm{CO} 2 \\
\text { levels. (FtF 98) A warmer climate will melt polar ice caps } \\
\text { and mountain glaciers,... (Gl World Geo 333) }\end{array}$ \\
\hline $\begin{array}{l}\text { ecosystem- } \\
\text { Flora/Fauna }\end{array}$ & $\begin{array}{l}\text { change in quantity or living } \\
\text { conditions of non-agricultural } \\
\text { flora/fauna }\end{array}$ & $\begin{array}{l}\text { Any long-term change in climate will affect ecosystems. } \\
\text { New organisms may be able to live in places where they } \\
\text { once could not. Other organisms may become threatened or } \\
\text { extinct in areas where they once thrived. (PH-Biology; p. } \\
\text { 159) }\end{array}$ \\
\hline society & $\begin{array}{l}\text { impacts that change patterns of } \\
\text { human settlement, trade, } \\
\text { movement/migration, and other } \\
\text { aspects of human society }\end{array}$ & $\begin{array}{l}\text { Increasing illness, hunger, flooding, and drought will likely } \\
\text { lead to forced migrations of tens of millions of } \\
\text { people...(Living in the Env, p. 513) }\end{array}$ \\
\hline human health & $\begin{array}{l}\text { increase/decrease in conditions } \\
\text { harmful to human health including } \\
\text { disease vectors, heat/cold related } \\
\text { deaths, } \mathrm{H} 2 \mathrm{O} \text { borne illness, etc. }\end{array}$ & $\begin{array}{l}\text { Susceptibility to tick-borne diseases like Lyme disease and } \\
\text { mosquito-borne diseases like malaria will } \\
\text { increase. Children and elderly persons are most susceptible } \\
\text { to these diseases. (Facing the Future, p. 28) }\end{array}$ \\
\hline \multicolumn{3}{|c|}{ Where - locations that are or will be threatened by GCC } \\
\hline Sub-Code & Definition & Example \\
\hline close & $\begin{array}{l}\text { locations within the continental } \\
\text { U.S. }\end{array}$ & $\begin{array}{l}\text { This rise would completely flood some countries, such as } \\
\text { the Netherlands, along with some coastal cities in the } \\
\text { United States, such as New york City, and low-lying states, } \\
\text { such as Florida and Louisiana. (Gl-Earth Science; p. 445) }\end{array}$ \\
\hline
\end{tabular}


CLIMATE CHANGE IN U.S. HIGH SCHOOL CURRICULA 70

\begin{tabular}{|c|c|c|}
\hline far & $\begin{array}{l}\text { locations outside of the } \\
\text { continental U.S. }\end{array}$ & $\begin{array}{l}\text { The widespread trend toward global warming is happening } \\
\text { at a dramatic pace in western Siberia. (Gl-World Geo; p. } \\
\text { 398) }\end{array}$ \\
\hline indeterminate & general locations not specified & $\begin{array}{l}\text { Rapid water evaporation from soil, however, will cause } \\
\text { land to dry out more quickly between rains. Some areas } \\
\text { may even become drier than before. (Gl-World Geo; p. } 53 \text { ) }\end{array}$ \\
\hline \multicolumn{3}{|c|}{ When - information concerning when the impacts of GCC will be seen } \\
\hline Sub-Code & Definition & Example \\
\hline now & $\begin{array}{l}\text { impacts already observed as } \\
\text { directly stated or implied by use of } \\
\text { present tense }\end{array}$ & $\begin{array}{l}\text { The burning of fossil fuels has raised the amounts of } \\
\text { carbon dioxide in the atmosphere, increasing global } \\
\text { temperatures. (Gl-World Geo; p. 333) }\end{array}$ \\
\hline soon & impacts observable by $2100 \mathrm{AD}$ & $\begin{array}{l}\text { Scientists predict that by the year } 2100 \text {, temperatures could } \\
\text { increase by more than another } 5 \mathrm{C} \text {. (PH-Earth } S c i ; \text { p. } 602)\end{array}$ \\
\hline indeterminate & $\begin{array}{l}\text { impacts to take effect at some time } \\
\text { in indeterminable future }\end{array}$ & $\begin{array}{l}\text { This rise in sea levels would cause flooding around } \\
\text { coastlines, where many cities are located. (H-McD-Earth } \\
\text { Sci; p. 619) }\end{array}$ \\
\hline
\end{tabular}

